\title{
High Stability of a Donor-Acceptor Type Oxazepine-Containing Fluorophore and Its Applications in Cellular Imaging and Two- photon Deep Tissue Imaging
}

Heejo Moon, Yuna Jung, Youngseo Kim, Byeong Wook Kim, Jin Gyu Choi, Na Hee Kim, Myung Sook Oh, Sungnam Park,* B. Moon Kim,* and Dokyoung Kim*

* To whom correspondence should be addressed:

dkim@khu.ac.kr (D.K), kimbm@snu.ac.kr (B.M.K), spark8@korea.ac.kr (S.P)

\section{Table of Contents}

Scheme S1. Synthetic method of OXN-1 and OXN-2

Figure S1. Solvent-dependent absorption and emission spectra of OXN-1 and OXN-2

Figure S2. Comparison absorption and emission spectra of OXN-1 and OXN-2

Figure S3. Fluorescence quantum yield analysis of OXN-1 and OXN-2

Figure S4. Fluorescence life-time analysis $\mathrm{OXN}-\mathbf{1}$ and $\mathbf{O X N - 2}$

Figure S5. LC-MS hydrolytic stability test result of OXN-1

Figure S6. Hydrolysis mechanism of OXN-2

Figure S7. pH-dependent absorption and emission spectra of OXN-1 and OXN-2

Figure S8. Photophysical property of ONX-1 in various bio-fluid

Figure S9. Photostability assay of $\mathbf{O X N - 1}$ and $\mathbf{O X N}-2$

Figure S10. HOMO-LUMO of $\mathbf{O X N - 1}$ and $\mathbf{O X N - 2}$

Figure S11. Ring formation mechanism of $\mathbf{O X N - 1}$

Figure S12. Time-dependent absorption and emission spectra of OXN-1 with glutathione

Figure S13. CLSM images for cells with OXN-1

Figure S14. TPACS values of $\mathbf{O X N - 1}$

Figure S15. TPM tissue images with OXN-1

Figure S16. Depth dependent TPM tissue images with OXN-1

Table S1. Photophysical properties of OXN-1 and OXN-2

Table S2. DFT calculation results for $\mathbf{O X N - 1}$ and $\mathbf{O X N - 2}$ 


\section{Experiments}

\section{Synthesis}

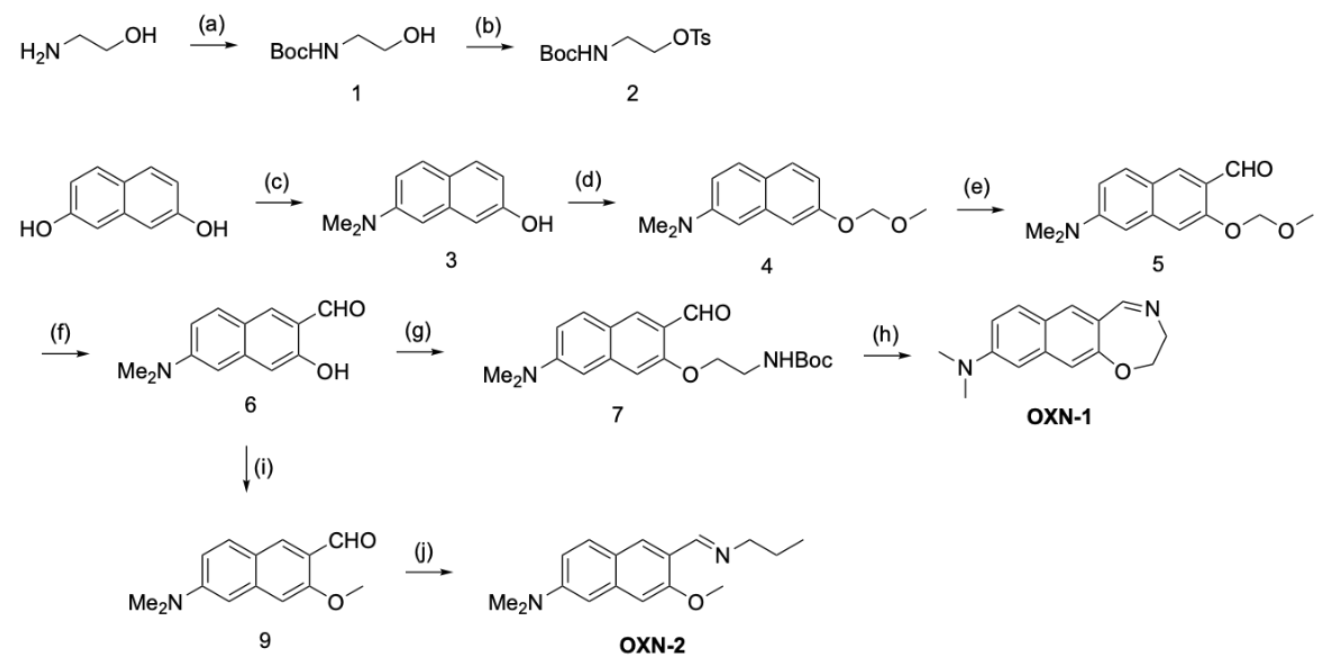

Scheme S1. Reagents and conditions: (a) Boc $2 \mathrm{O}$, TEA, DCM, $0{ }^{\circ} \mathrm{C}$ to $25^{\circ} \mathrm{C}, 77 \%$; (b) $p$-TsCl, TEA, DCM, 0 ${ }^{\circ} \mathrm{C}$ to $25{ }^{\circ} \mathrm{C}, 16 \mathrm{~h}, 80 \%$; (c) $\mathrm{Na}_{2} \mathrm{~S}_{2} \mathrm{O}$, $\mathrm{Me}_{2} \mathrm{NH}, \mathrm{H}_{2} \mathrm{O}, 150{ }^{\circ} \mathrm{C}, 2 \mathrm{~h}, 52 \%$; (d) $\mathrm{NaH}$, DMF, bromomethyl methyl ether, $0{ }^{\circ} \mathrm{C}$ to $25^{\circ} \mathrm{C}, 79 \%$; (e) $t$-BuLi, Et $2 \mathrm{O}$, DMF, $-15^{\circ} \mathrm{C}, 3 \mathrm{~h}, 45 \%$; (f) $\mathrm{HCl}, i \mathrm{PrOH}, 60{ }^{\circ} \mathrm{C}, 3 \mathrm{~h}, 80 \%$; (g) $\mathrm{NaH}$, 2, DMF, $0{ }^{\circ} \mathrm{C}$ to $25^{\circ} \mathrm{C}, 6 \mathrm{~h}, 50 \%$; (h) TFA, DCM, $25{ }^{\circ} \mathrm{C}, 3 \mathrm{~h}, 99 \%$; (i) NaH, DMF, MeI, $0{ }^{\circ} \mathrm{C}$ to $25^{\circ} \mathrm{C}, 4 \mathrm{~h}$, $50 \%$; (j) Propylamine, $\mathrm{MgSO}_{4}, \mathrm{DCM}, 25{ }^{\circ} \mathrm{C}, 24 \mathrm{~h}, 89 \%$.

\section{Experimental Details}

\section{1. Materials and methods}

The chemical reagents were purchased from Aldrich (US), TCI (Japan), Alfa Aesar (US), and Acros Organics (US). Fluorescent agents, LysoTracker ${ }^{\mathrm{TM}}$ Deep-Red and MitoTracker ${ }^{\mathrm{TM}}$ Deep-Red (ThermoFisher, US), were used for the specific cellular organ imaging experiment with $\mathrm{OXN}$ series. The $\mathrm{pH}$ range was 4-9 including biological $\mathrm{pH}$ (7.4) for the $\mathrm{pH}$ screening. Commercially available reagents and anhydrous solvents were used without further purification. Chemical reactions were performed under argon atmosphere. TLC (thin-layer chromatography) was performed on the pre-coated silica gel 60F-254 glass plates (Merck KGaA, Germany). ${ }^{1} \mathrm{H}$ and ${ }^{13} \mathrm{C}$ NMR Spectra were recorded on a Varian/Oxford As-500 (500 MHz) spectrophotometer in the indicated solvent. In the NMR spectra, the chemical shifts $(\delta)$ are reported in ppm, multiplicities are indicated by s (singlet), d (doublet), $\mathrm{t}$ (triplet), dd (double of doublets), and m (multiplet). Spectra are referenced to residual chloroform (7.26 ppm). Coupling constants were reported in Hz. Chemical shifts were reported as parts per million $(\mathrm{ppm})$ relative to the signal $(0.00 \mathrm{ppm})$ for internal tetramethylsilane (TMS) for solutions in $\mathrm{CDCl}_{3}\left(7.26 \mathrm{ppm}\right.$ for ${ }^{1} \mathrm{H}, 77.0 \mathrm{ppm}$ for $\left.{ }^{13} \mathrm{C}\right)$ or DMSO-d 6 (2.50 ppm for ${ }^{1} \mathrm{H}$ and $39.5 \mathrm{ppm}$ for ${ }^{13} \mathrm{C}$ ). Liquid chromatography-mass spectrometry (LC-MS) spectra were measured on an Agilent HP 1260 system (Agilent Technologies, Santa Clara, US). High resolution mass spectrometry (HRMS) of final compounds was further confirmed by Ultra High Resolution ESI Q-TOF mass spectrometer (Bruker, US) from Organic Chemistry Research Center at Sogang University, Rep. of Korea. 


\subsection{Preparation of compounds}

The procedures used in the synthesis of compound 1-7 and OXN-1/OXN-2 are summarized in Scheme S1, respectively. The key intermediate, compound $\mathbf{6}$, was prepared by following the reported method (Ref. 1).

tert-Butyl (2-hydroxyethyl)carbamate (1). To the mixture of ethanolamine $(1.98 \mathrm{~mL}, 32.7 \mathrm{mmol})$ and trimethylamine $(6.84 \mathrm{~mL}, 49.0 \mathrm{mmol})$ in DCM $(100 \mathrm{~mL})$ was added di-tert-butyl dicarbonate $(8.26 \mathrm{~mL}, 36.0$ mmol) slowly at $0{ }^{\circ} \mathrm{C}$. The reaction mixture was stirred overnight while gradually being warmed up to room temperature $\left(25^{\circ} \mathrm{C}\right)$. The crude mixture was washed with brine, dried over $\mathrm{MgSO}_{4}$, and concentrated in vacuo. Then, the residue was purified by flash column chromatography ( $n$-hexane/ethyl acetate $=1: 1, v / v)$ to furnish compound 1 as a colorless oil (4.07 g, 77\%). ${ }^{1} \mathrm{H}$ NMR (500 MHz, $\left.\mathrm{CDCl}_{3}\right): \delta 1.45$ (s, 9H), 3.03 (s, $\left.1 \mathrm{H}\right), 3.28$ (q, $\mathrm{J}=4.0 \mathrm{~Hz}, 2 \mathrm{H}), 3.69(\mathrm{q}, \mathrm{J}=4.0 \mathrm{~Hz}, 2 \mathrm{H}), 5.12(\mathrm{~s}, 1 \mathrm{H}) ;{ }^{13} \mathrm{C} \mathrm{NMR}(500 \mathrm{MHz}, \mathrm{CDCl} 3): \delta 28.3,43.1,62.4,79.6$, 156.8. HRMS $(m / z)$ : $[\mathrm{M}+\mathrm{Na}]^{+}$calcd for $\mathrm{C}_{7} \mathrm{H}_{15} \mathrm{NNaO}_{3}, 184.0944$; found, 184.0947 .

2-((tert-Butoxycarbonyl)amino)ethyl 4-methylbenzenesulfonate (2). To a cooled (ice-bath) solution of compound $1(1.0 \mathrm{~g}, 6.20 \mathrm{mmol})$ and trimethylamine $(1.99 \mathrm{~mL}, 14.3 \mathrm{mmol})$ in DCM $(9 \mathrm{~mL})$, was added a solution of $p$-toluenesulfonyl chloride $(1.30 \mathrm{~g}, 6.82 \mathrm{mmol})$ in DCM $(9 \mathrm{~mL})$ dropwise. The reaction was allowed to stir at ambient temperature overnight. The reaction mixture was washed with $0.1 \mathrm{M} \mathrm{HCl} \mathrm{(aq),} \mathrm{brine,}$ and dried over $\mathrm{MgSO}_{4}$. All the volatile components were removed in vacuo, and the crude residue was purified by column chromatography ( $n$-hexane/ethyl acetate $=3: 1, v / v)$ to give compound 2 as a white solid $(1.54 \mathrm{~g}$, 80\%). ${ }^{1} \mathrm{H}$ NMR (400 MHz, $\left.\mathrm{CDCl}_{3}\right): \delta 1.39$ (s, 9H), 2.43 (s, 3H), 3.37 (d, J = 4.0 Hz, 2H), 4.05 (t, J = 4.0 Hz, $2 \mathrm{H}), 4.87(\mathrm{~s}, 1 \mathrm{H}), 7.34(\mathrm{~d}, \mathrm{~J}=8.0 \mathrm{~Hz}, 2 \mathrm{H}), 7.77(\mathrm{~d}, \mathrm{~J}=8.0 \mathrm{~Hz}, 2 \mathrm{H}) ;{ }^{13} \mathrm{C} \mathrm{NMR}\left(400 \mathrm{MHz}, \mathrm{CDCl}_{3}\right): \delta 21.6$, 28.3, 39.7, 69.4, 79.8, 127.9, 129.9, 132.6, 145.0, 155.6. HRMS $(m / z):[\mathrm{M}+\mathrm{Na}]^{+}$calcd for $\mathrm{C}_{14} \mathrm{H}_{21} \mathrm{NNaO}_{5} \mathrm{~S}$, 338.1033; found, 338.1035 .

tert-Butyl (2-((7-(dimethylamino)-3-formylnaphthalen-2-yl)oxy)ethyl)carbamate (7). Compound 3-6 were prepared according to the reported procedure (Ref. 1). To a suspension of sodium hydride $(60 \%$ dispersed in mineral oil, $11 \mathrm{mg}, 0.26 \mathrm{mmol})$ in DMF $(0.5 \mathrm{~mL})$ was added a solution of compound 6 (50 mg, $0.23 \mathrm{mmol})$ in DMF $(0.5 \mathrm{~mL})$ dropwise at $0{ }^{\circ} \mathrm{C}$. The mixture was agitated for $30 \mathrm{~min}$, followed by the addition of compound $2(88 \mathrm{mg}, 0.28 \mathrm{mmol})$ in DMF $(0.1 \mathrm{~mL})$. After additional $10 \mathrm{~min}$, the reaction was allowed to stir at ambient temperature until starting material disappeared in TLC analysis. The reaction was quenched with sat aq $\mathrm{NH}_{4} \mathrm{Cl}$ solution and diluted with ethyl acetate. Subsequently, two layers were separated and the aqueous layer was extracted with ethyl acetate, two times. The organic layers were combined, dried over $\mathrm{MgSO}_{4}$, and filtered through a sintered glass filter. All the volatile components were removed under vacuum. Column chromatography ( $n$-hexane/ethyl acetate $=9: 1$ to $4: 1, v / v)$ afforded the desired compound 7 as a yellow solid (41 mg, 50\%). ${ }^{1} \mathrm{H}$ NMR (500 MHz, $\left.\mathrm{CDCl}_{3}\right): \delta 1.46$ (s, 9H), $3.10(\mathrm{~s}, 6 \mathrm{H}), 3.65$ (d, J = 5.0 Hz, 2H), 4.19 (t, $\mathrm{J}=5.0 \mathrm{~Hz}, 2 \mathrm{H}), 5.10(\mathrm{~s}, 1 \mathrm{H}), 6.71(\mathrm{~s}, 1 \mathrm{H}), 6.91(\mathrm{~s}, 1 \mathrm{H}), 7.00(\mathrm{dd}, \mathrm{J}=5.0 \mathrm{~Hz}, 1 \mathrm{H}), 7.71(\mathrm{~d}, \mathrm{~J}=5.0 \mathrm{~Hz}, 1 \mathrm{H})$, 
8.19 (s, 1H), 10.42 (s, 1H); ${ }^{13} \mathrm{C}$ NMR (500 MHz, $\left.\mathrm{CDCl}_{3}\right): \delta 28.4,40.1,40.3,67.6,79.7,104.0,104.9,114.4$, 120.7, 121.9, 131.2, 131.7, 139.8, 150.8, 156.0, 157.3, 189.4. HRMS $(m / z):[\mathrm{M}+\mathrm{Na}]^{+}$calcd for $\mathrm{C}_{20} \mathrm{H}_{26} \mathrm{~N}_{2} \mathrm{NaO}_{4}$, 381.1785; found, 381.1783 .

N,N-Dimethyl-2,3-dihydronaphtho[2,3-f][1,4]oxazepin-9-ammonium trifluoroacetate (OXN-1). Compound $7(20 \mathrm{mg}, 56 \mu \mathrm{mol})$ was dissolved in TFA (trifluoroacetic acid)/DCM (1:1, $/ / v, 0.8 \mathrm{~mL})$ solution, and the mixture was agitated for $3 \mathrm{~h}$ at ambient temperature. The completion of the reaction was monitored via LCMS analysis. All the volatile components were removed under reduced pressure to yield the TFA salt of $\mathbf{O X N}$ 1 as a reddish solid (19 mg, 99\%). ${ }^{1} \mathrm{H}$ NMR (400 MHz, $\left.\mathrm{CDCl}_{3}\right): \delta 3.21(\mathrm{~s}, 6 \mathrm{H}), 4.19(\mathrm{t}, \mathrm{J}=4.0 \mathrm{~Hz}, 2 \mathrm{H}), 4.46(\mathrm{t}$, $\mathrm{J}=4.0 \mathrm{~Hz}, 2 \mathrm{H}), 6.69(\mathrm{~d}, \mathrm{~J}=2.0 \mathrm{~Hz}, 1 \mathrm{H}), 7.09(\mathrm{dd}, \mathrm{J}=4.0,8.0 \mathrm{~Hz}, 1 \mathrm{H}), 7.16(\mathrm{~s}, 1 \mathrm{H}), 7.77(\mathrm{~d}, \mathrm{~J}=8.0 \mathrm{~Hz}, 1 \mathrm{H})$, 8.13 (s, 1H), 8.71 (s, 1H), 10.08 (s, 1H); $\left.{ }^{13} \mathrm{C} \mathrm{NMR} \mathrm{(400} \mathrm{MHz,} \mathrm{CDCl}_{3}\right): \delta 40.4,51.5,66.9,103.3,112.1,113.3$, 115.4 (TFA, m), 115.8, 122.4, 132.4, 142.0, 145.4, 153.0, 156.4, 160.7 (TFA, m), 165.0. TFA: trifluoroacetic acid. HRMS $(\mathrm{m} / z)$ : $[\mathrm{M}+\mathrm{H}]^{+}$calcd for $\mathrm{C}_{15} \mathrm{H}_{17} \mathrm{~N}_{2} \mathrm{O}, 241.1335$; found, 241.1336.

6-(Dimethylamino)-3-methoxy-2-naphthaldehyde (9) (6-DMMNA). To a dispersion of sodium hydride (60\% in mineral oil, $11 \mathrm{mg}, 0.29 \mathrm{mmol})$ in DMF $(0.5 \mathrm{~mL})$ was added a solution of compound 6 (50 mg, $0.23 \mathrm{mmol})$ in $\mathrm{DMF}(0.5 \mathrm{~mL})$ dropwise at $0{ }^{\circ} \mathrm{C}$. The mixture was stirred for $30 \mathrm{~min}$. Then, iodomethane $(16 \mu \mathrm{L}, 0.26$ $\mathrm{mmol})$ in DMF $(0.1 \mathrm{~mL})$ was added to the reaction mixture. After $10 \mathrm{~min}$, the reaction temperature was raised to ambient temperature. After $4 \mathrm{~h}$, sat aq $\mathrm{NH}_{4} \mathrm{Cl}$ solution was poured into the reaction mixture. Subsequently, the aqueous layer was extracted with ethyl acetate, three times. The organic layers were combined, dried over $\mathrm{MgSO}_{4}$, and filtered. The crude mixture was concentrated under reduced pressure. Column chromatography ( $n$-hexane/ethyl acetate $=9: 1, v / v)$ afforded compound 9 as a yellow solid $(27 \mathrm{mg}, 50 \%) .{ }^{1} \mathrm{H}$ NMR (500 MHz, CDCl 3 ): $\delta 3.10(\mathrm{~s}, 6 \mathrm{H}), 3.97$ (s, 3H), 6.73 (d, J = 5.0 Hz, 1H), $6.93(\mathrm{~s}, 1 \mathrm{H}), 6.98(\mathrm{dd}, \mathrm{J}=2.5$, $10.0 \mathrm{~Hz}, 1 \mathrm{H}), 7.70(\mathrm{~d}, \mathrm{~J}=5.0 \mathrm{~Hz}, 1 \mathrm{H}), 8.19(\mathrm{~s}, 1 \mathrm{H}), 10.42(\mathrm{~s}, 1 \mathrm{H}) ;{ }^{13} \mathrm{C} \mathrm{NMR}\left(500 \mathrm{MHz}, \mathrm{CDCl}_{3}\right): \delta 40.3$, $55.41,55.43,103.9,104.0,114.2,120.7,122.1,131.19,131.23,139.9,150.8,189.7$. HRMS $(m / z):[M+H]^{+}$ calcd for $\mathrm{C}_{14} \mathrm{H}_{15} \mathrm{NNaO}_{2}, 252.0995$; found, 252.0997.

(E)-7-Methoxy-N,N-dimethyl-6-((propylimino)methyl)naphthalen-2-amine (OXN-2). Compound 9 (10 mg, 44 $\mu \mathrm{mol})$ and 1-propylamine ( $4 \mu \mathrm{L} .48 \mu \mathrm{mol})$ were dissolved in DCM $(200 \mu \mathrm{L})$, followed by the addition of $\mathrm{MgSO}_{4}(11 \mathrm{mg}, 88 \mu \mathrm{mol})$ in one portion. The reaction was stirred for $24 \mathrm{~h}$ at ambient temperature. Subsequently, the mixture was diluted with DCM, and filtered through a sintered glass filter. All the volatile components were removed under vacuum to give $\mathbf{O X N}-\mathbf{2}$ as a reddish solid $(11 \mathrm{mg}, 89 \%)$. ${ }^{1} \mathrm{H}$ NMR (500 $\left.\mathrm{MHz}, \mathrm{CDCl}_{3}\right): \delta 0.98(\mathrm{t}, \mathrm{J}=7.5 \mathrm{~Hz}, 3 \mathrm{H}), 1.72-1.79(\mathrm{~m}, 2 \mathrm{H}), 3.06(\mathrm{~s}, 6 \mathrm{H}), 3.60-3.63(\mathrm{~m}, 2 \mathrm{H}), 3.94(\mathrm{~s}, 3 \mathrm{H})$, $6.78(\mathrm{~d}, \mathrm{~J}=2.5 \mathrm{~Hz}, 1 \mathrm{H}), 6.95(\mathrm{~s}, 1 \mathrm{H}), 6.99(\mathrm{dd}, \mathrm{J}=2.5,7.5 \mathrm{~Hz}, 2 \mathrm{H}), 7.68(\mathrm{~d}, \mathrm{~J}=10.0 \mathrm{~Hz}, 1 \mathrm{H}), 8.27(\mathrm{~s}, 1 \mathrm{H})$, $8.74(\mathrm{t}, \mathrm{J}=5.0 \mathrm{~Hz}, 1 \mathrm{H}) ;{ }^{13} \mathrm{C} \mathrm{NMR}\left(500 \mathrm{MHz}, \mathrm{CDCl}_{3}\right): \delta 11.9,24.3,40.6,55.3,63.9,103.7,104.7,114.1$, 
127.1, 129.8, 137.4, 149.5, 156.9, 157.3, 160.7. HRMS (m/z): $[\mathrm{M}+\mathrm{H}]^{+}$calcd for $\mathrm{C}_{17} \mathrm{H}_{23} \mathrm{~N}_{2} \mathrm{O}, 271.1805$; found, 271.1806 .

\subsection{UV/Vis and fluorescence spectroscopic methods}

UV/Vis absorption spectra were obtained using spectrophotometer (Agilent Technologies Cary 8454, US). Fluorescence emission spectra were recorded on a spectrofluorophotometer (SHIMADZU CORP. RF-6000, Japan) with a $1 \mathrm{~cm}$ standard quartz cell. The stock solution of OXN series was prepared by dissolving them in dimethyl sulfoxide (DMSO, $10 \mathrm{mM}$ ). The cuvette for absorbance and fluorescence measurements was made from quartz and have an internal volume of $1 \mathrm{~mL}$.

\subsection{Cell culture}

HeLa cell line was obtained from the Korean Cell Line Bank. Cells were cultured in Dulbecco's modified Eagle's media (Hyclone, US) supplemented with 10\% fetal bovine serum (Hyclone) and 1\% penicillinstreptomycin (Gibco). Cultures were incubated at $37{ }^{\circ} \mathrm{C}$ in humidified air containing $5 \% \mathrm{CO}_{2}$.

\subsection{Cell viability assay}

Approximately $5 \times 10^{4}$ cells were seeded on a 96-well clear bottom plate (SPL Life Science, Ref. of Korea) and incubated for $24 \mathrm{~h}$. After incubation, the cells were treated with DMSO as a control and OXN-1 for $24 \mathrm{~h}$. The cell viability was analyzed by Vybrant ${ }^{\circledR}$ MTT Cell Proliferation Assay Kit (ThermoFisher, US ) followed by manufacturer's instructions. The absorbance level was analyzed at $550 \mathrm{~nm}$ by microplate reader (Multiskan ${ }^{\mathrm{TM}}$ FC Microplate Photometer, ThermoFisher, US). The treated wells relative to that in the control and the culture medium was used as a control.

\subsection{CLSM imaging for cells}

Approximately $2 \times 10^{5}$ cells were seeded on 35-mm glass bottom confocal dishes (SPL Life Science, Rep. of Korea) and incubated for $24 \mathrm{~h}$. At the 80\% confluency, OXN-1 (20 $\mu \mathrm{M}$ in DMSO) was treated to cells for 2 $\mathrm{h}$ at $37^{\circ} \mathrm{C}$ in $5 \% \mathrm{CO}_{2}$. Fluorescence images were visualized by a confocal laser scanning microscope (CLSM, LSM-800, Carl Zeiss, Germany). Excitation and emission channel; yellow (543 nm, 450-617 nm band filter) and red (663 $\mathrm{nm}, 645-700 \mathrm{~nm}$ band filter).

\subsection{Tissue sample preparation}

We used a male ICR mouse (8-weeks-old) that were purchased from the Daehan Biolink Co. Ltd. (Eumseong, Republic of Korea) in this study. The mouse was accommodated in a constant temperature $\left(23 \pm 1^{\circ} \mathrm{C}\right)$, humidity $(60 \pm 10 \%)$, and a $12 \mathrm{~h} \mathrm{light/dark} \mathrm{cycle} \mathrm{with} \mathrm{free} \mathrm{access} \mathrm{to} \mathrm{water} \mathrm{and} \mathrm{food.} \mathrm{The} \mathrm{mouse} \mathrm{was} \mathrm{handled}$ by the Principle of Laboratory Animal Care (NIH Publication No. 80-23; revised 1978) and the Animal Care and Use Guidelines of Kyung Hee University, Seoul, Republic of Korea (approval number: KHUASP(SE)- 
18-123). The tissue samples of mouse brain, lung, liver, kidney, stomach, and large intestine was prepared after the perfusion of $0.1 \mathrm{M}$ phosphate buffered saline (PBS) according to the previous reported study (Ref: PMID 29352191).

\subsection{Quantum chemical calculations}

All calculations were carried out using the density functional theory (DFT) and time-dependent DFT (TDDFT) methods at the B3LYP-d3 level with the $6-31+\mathrm{G}(\mathrm{d}, \mathrm{p})$ basis set as implemented in the Gaussian 09 package. The optimized structures and frontier orbitals (HOMO and LUMO) of OXN series were obtained using the DFT method and electronic absorption spectra were calculated using the TD-DFT method. The integral equation formalism polarizable continuum (IEF-PCM) model was used for solvation (Ref. 2).

\subsection{Hydrolytic Stability Test}

The hydrolytic stability of OXN series was analyzed by means of LC-MS analysis in various pH points $(1,4$, $7.2,9,11)$ at different time points $(1 \mathrm{~h}, 3 \mathrm{~h}$, and $24 \mathrm{~h})$. A stock solution of OXN series $(10 \mathrm{mM})$ in DMSO was prepared immediately before diluting with aqueous media. The stock solution of OXN series was added to a buffer solution with indicated $\mathrm{pH}$ at room temperature $\left(25^{\circ} \mathrm{C}\right)$ to give a final concentration of $50 \mu \mathrm{M}(5 \%$ DMSO/aqueous buffer), and the mixture was stirred at the same temperature for indicated time. An aliquot (50 $\mu \mathrm{L}$ ) of the resulting solution was taken by micropipette, and diluted with $150 \mu \mathrm{L}$ of $\mathrm{MeOH}$. The subsequent mixture was filtered through a $0.45 \mu \mathrm{m}$ syringe filter and analyzed via LC-MS.

\subsection{Time-resolved fluorescence spectroscopy}

Time-resolved fluorescence (TRF) signals, $S(t)$, of OXN series were collected at a series of wavelengths by using a time-correlated single-photon counting (TCSPC) method. The sample solutions of OXN series were excited by a $375 \mathrm{~nm}$ pulse (LDH-P-C-375, PicoQuant). The emitted fluorescence of OXN-1 and OXN-2 was measured at 455 and $465 \mathrm{~nm}$ by using a photo-multiplier tube (PMA 182, PicoQuant), respectively. To determine the fluorescence lifetimes, the TRF signals were fit by a single exponential function, $S(t)=A \exp (-$ $t / \tau)$.

\subsection{Bio-fluid Stability Test}

We used a male ICR mouse (8-weeks-old) that were purchased from the Daehan Biolink Co. Ltd. (Eumseong, Republic of Korea) in this study. The mouse was accommodated in a constant temperature $\left(23 \pm 1^{\circ} \mathrm{C}\right)$, humidity $(60 \pm 10 \%)$, and a $12 \mathrm{~h} \mathrm{light/dark} \mathrm{cycle} \mathrm{with} \mathrm{free} \mathrm{access} \mathrm{to} \mathrm{water} \mathrm{and} \mathrm{food.} \mathrm{The} \mathrm{mouse} \mathrm{was} \mathrm{handled}$ by the Principle of Laboratory Animal Care (NIH Publication No. 80-23; revised 1978) and the Animal Care and Use Guidelines of Kyung Hee University, Seoul, Republic of Korea (approval number: KHUASP(SE)18-123). The preparation of mouse gastric juice was performed by the previous reported study with a few modification (Ref: PMID 18088506). Briefly, a mouse was fasted overnight and anesthetized by 
tribromoethanol $(20 \mu \mathrm{L} / \mathrm{g}$ of body weight). The upper pyloric and lower esophageal sphincters of mouse stomach were ligated with a suture for $4 \mathrm{~h}$ to induce gastric juice retention. After the ligation, a tiny hole was made on the mouse stomach and collected fluids. The fluids were centrifuged at $1500 \mathrm{rpm}$ for $5 \mathrm{~min}$ and the supernatant was collected as gastric juice. The samples of urine and blood were also collected at the same time.

Mouse urine (pH 5.0), gastric juice (pH 3.0), and human serum ( $\mathrm{pH} 7.4$ ) were prepared. Each $100 \mu \mathrm{L}$ of mouse urine and gastric juice was diluted by DI $\mathrm{H}_{2} \mathrm{O}$ (urine: $\mathrm{DI} \mathrm{H}_{2} \mathrm{O}=1: 2$, gastric juice:DI $\mathrm{H}_{2} \mathrm{O}=1: 5$ ). Human serum was also diluted by DI $\mathrm{H}_{2} \mathrm{O}$ (human serum:DI $\mathrm{H}_{2} \mathrm{O}=1: 10$ ). Next, OXN-1 was added to diluted bio-fluid, respectively. UV/Vis absorption and emission spectra of OXN-1 $(5 \mu \mathrm{M})$ were monitored at $25^{\circ} \mathrm{C}$. The cuvette for absorbance and fluorescence measurements was made from quartz and have an internal volume of $100 \mu \mathrm{L}$.

\subsection{TPM imaging}

The tissue samples were frozen on the dry ice for $3 \mathrm{~min}$. After then, frozen tissues were cut into several pieces with an average thickness of about $200 \mu \mathrm{m}$ by surgical blade (No.11, Reather safety razor Co.,LTD, Japan). The sliced tissues were transferred to 24-well plates (SPL Life Science, Rep. of Korea) and OXN-1 (50 $\mu$ M and $100 \mu \mathrm{M}$ ) were treated to each well (brain, lung, liver, kidney, stomach, and large intestine). After OXN1 was treated, the samples were incubated at $37{ }^{\circ} \mathrm{C}$ for $2 \mathrm{~h}$ and washed three times using PBS buffer and transferred to micro-centrifuge tube (\#60115, SPL Life Science, Rep. of Korea) including $1 \mathrm{~mL}$ of 4\% PFA. Two-photon microscopy (TPM) imaging experiments were performed through additional washing steps of tissues three times using PBS. Tissue images were visualized by a two-photon microscopy (TPM, TCS SP5, Leica microsystem, Germany). Excitation and emission channel; yellow (543 nm, 569-611 nm band filter).

\subsection{Quantum yield measurements}

The quantum yield of OXN series was determined using diphenylanthracene (DPA) as a reference based on the following equation, $\mathrm{QY}=\left(\mathrm{QY}\right.$ ref $\left.\times \eta^{2} \times I \times A_{\text {ref }}\right) /\left(\eta^{2}\right.$ ref $\left.\times I_{\text {ref }} \times A\right)$ where $A$ is the absorbance at an excitation wavelength, $\eta$ is the refractive index of solvents, and $I$ is the intensity of fluorescence which is obtained by calculating the area under the fluorescence spectrum. Experimental parameters for determining the quantum yield of OXN series are shown in Figure S3(c). 


\section{Supporting Figures}

(a) OXN-1
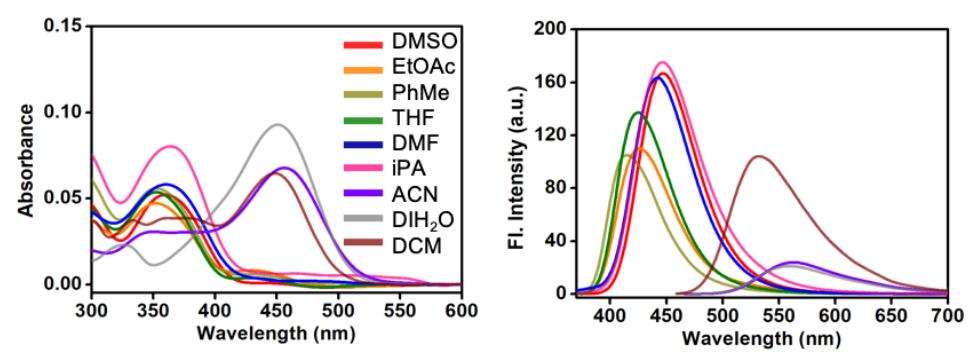

(b) OXN-2
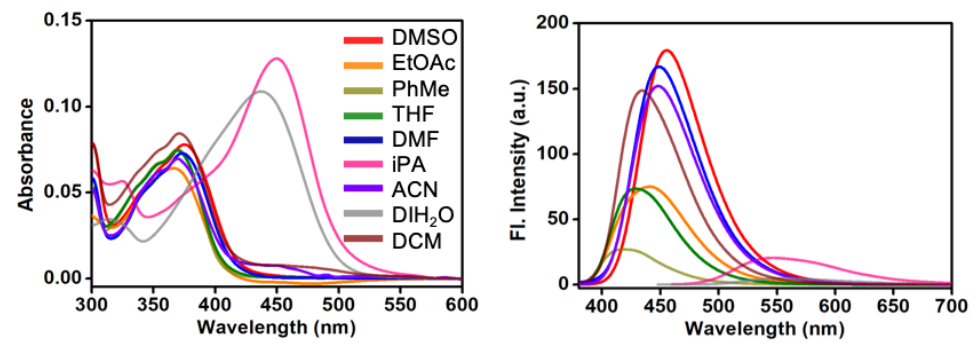

Figure S1. (a, b) UV/vis absorption (left) and emission (right) spectra of (a) OXN-1, (b) OXN-2 in various solvent. All the measurements were carried out at $25{ }^{\circ} \mathrm{C}$ for a solution of the $\mathrm{OXN}$ series $(5 \mu \mathrm{M})$ in the given solvent. The emission spectra were recorded under excitation at the maximum absorption wavelength. 

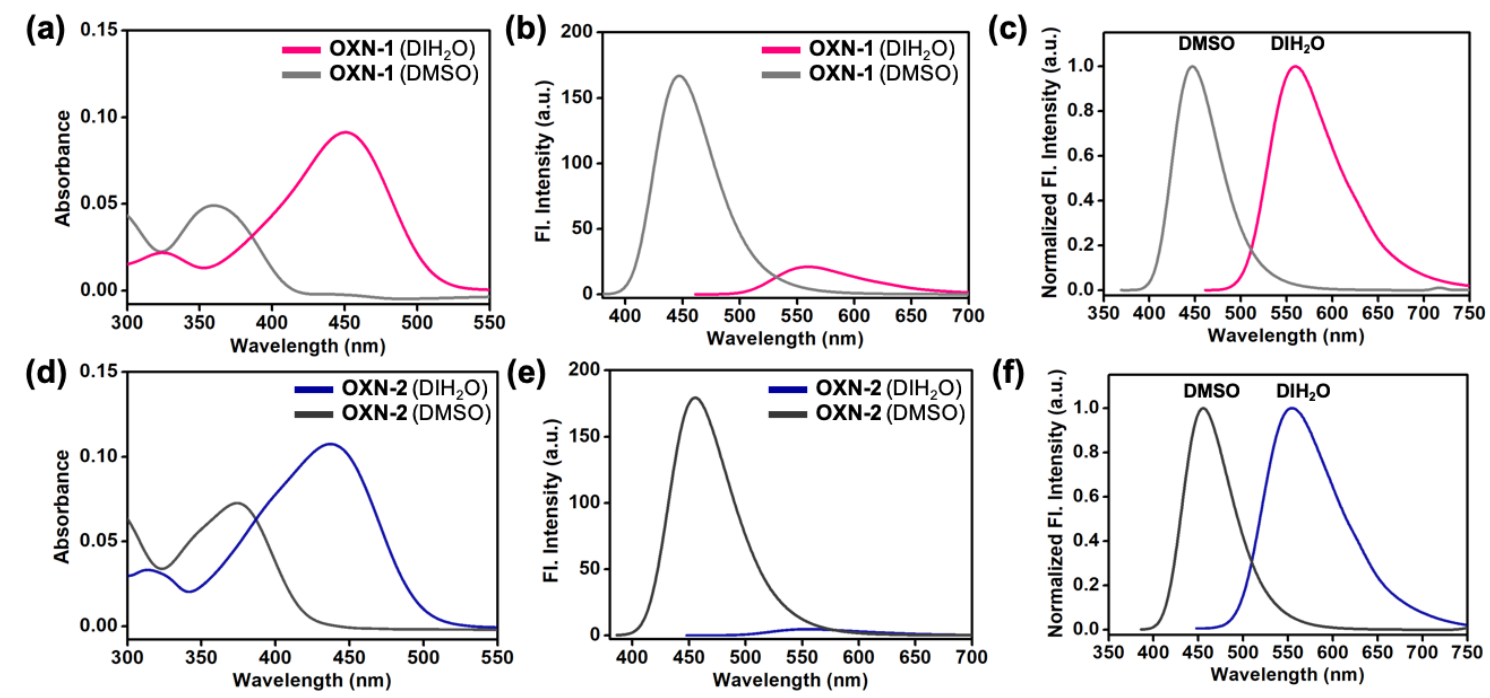

Figure S2. (a, d) UV/vis absorption and (b, e) emission spectra of OXN-1 and OXN-2 in $\mathrm{DI}_{2} \mathrm{H}_{2} \mathrm{O}$ and DMSO. (c, f) Normalized emission spectra of (c) OXN-1 and (f) OXN-2 in DI $\mathrm{H}_{2} \mathrm{O}$ and DMSO. All the measurements were carried out at $25{ }^{\circ} \mathrm{C}$ for a solution of the $\mathrm{OXN}$ series $(5 \mu \mathrm{M})$ in the given solvent. The emission spectra were recorded under excitation at the maximum absorption wavelength. 

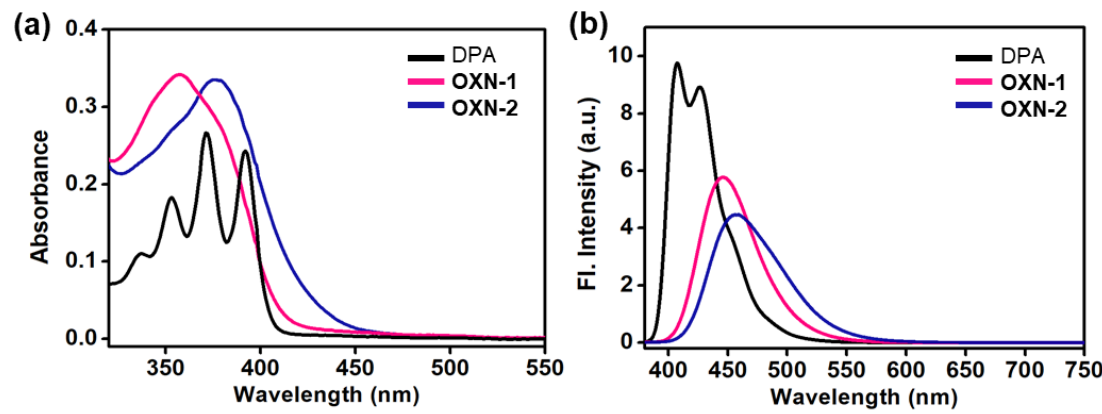

(c)

\begin{tabular}{|c|c|c|c|}
\hline & DPA (ref) & OXN-1 & OXN-2 \\
\hline$\lambda_{\text {exc } \max }(\mathrm{nm})$ & 371 & 371 & 371 \\
\hline$\eta$ & $1.3768(\mathrm{EtOH})$ & 1.5046 (DMSO) & 1.5046 (DMSO) \\
\hline $\mathrm{I}$ & 502766 & 355794 & 334079 \\
\hline $\mathrm{A}$ & 0.26636 & 0.30457 & 0.32791 \\
\hline$Q Y$ & 0.95 & $\mathbf{0 . 7 0}$ & $\mathbf{0 . 6 1}$ \\
\hline
\end{tabular}

Figure S3. Determination of the fluorescence quantum yield (QY). (a, b) Absorption and emission spectra of OXN-1 $(0.5 \mu \mathrm{M})$ and OXN-2 $(0.5 \mu \mathrm{M})$ in DMSO, and 9,10-diphenylanthracene (DPA) in ethanol. (c) Experimental parameters for determining the QY measurements of OXN series. 


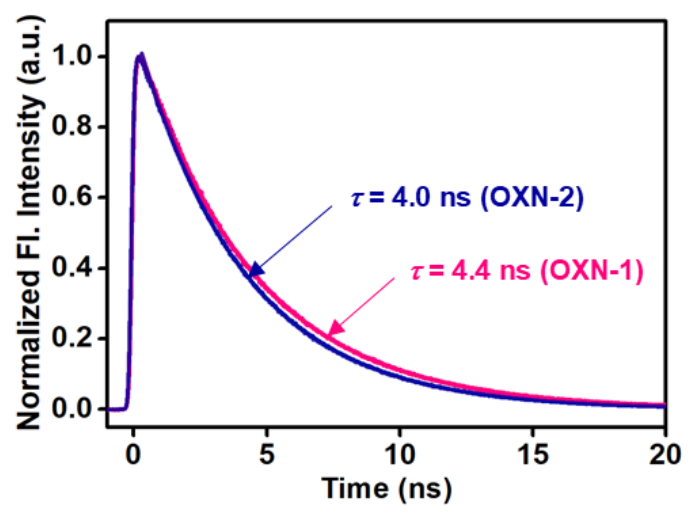

Figure S4. Fluorescence lifetime measurement. Time-resolved fluorescence (TRF) signals were measured at $455 \mathrm{~nm}$ for $\mathbf{O X N}-1(0.5 \mu \mathrm{M})$ and at $465 \mathrm{~nm}$ for $\mathbf{O X N}-2(0.5 \mu \mathrm{M})$ in DMSO, respectively, following excitation by a $375 \mathrm{~nm}$ pulse. The fluorescence lifetimes $(\tau)$ were obtained by a single exponential fit to the TRF signals. 

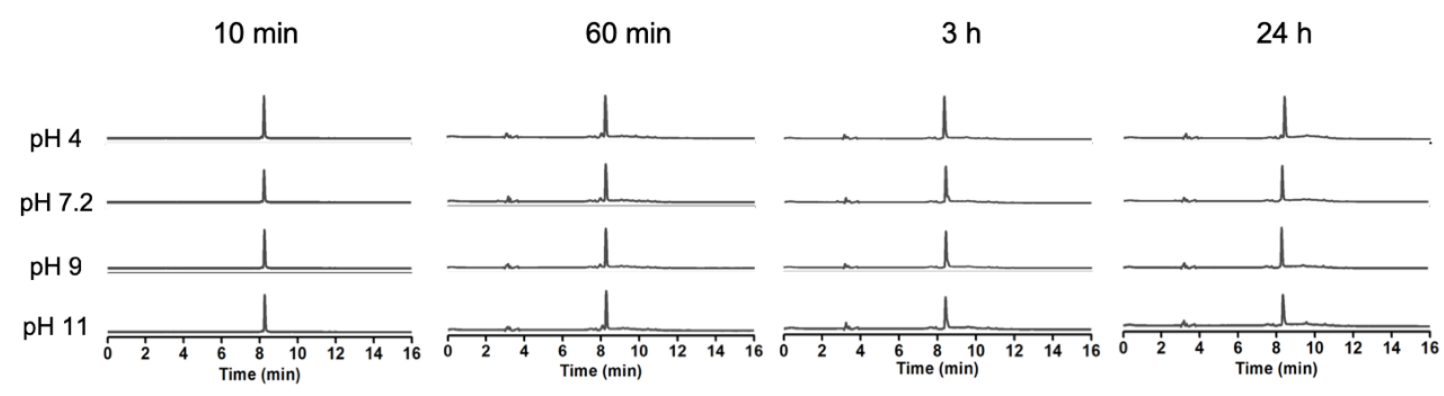

Figure S5. LC-MS hydrolytic stability test result of OXN-1. The peak change of OXN-1 (8.27 min) measured for 24 hours in various $\mathrm{pHs}$. 

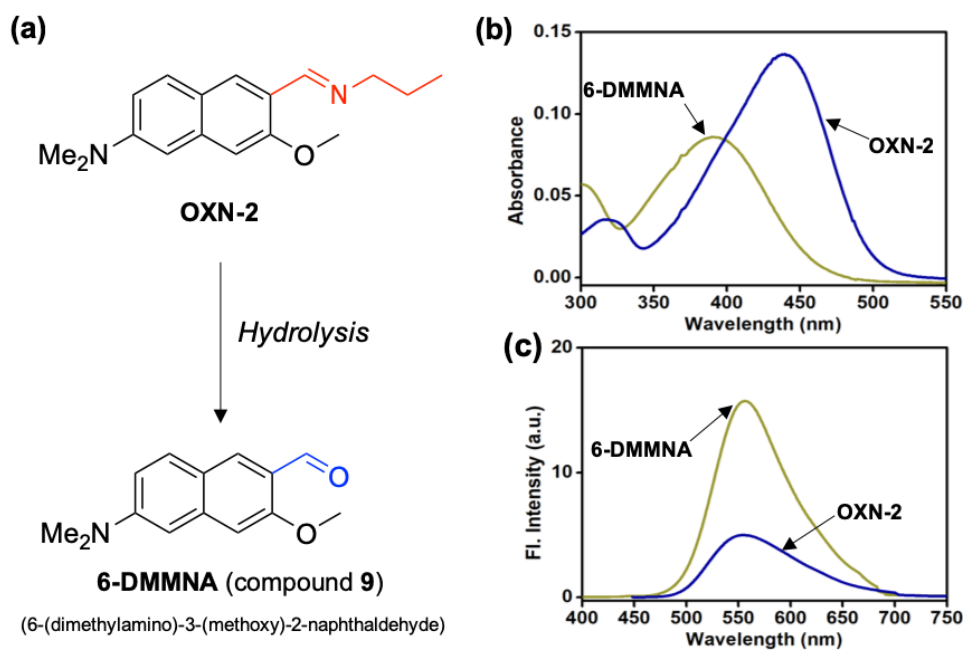

Figure S6. (a) The hydrolysis mechanism of OXN-2. (b) UV/vis absorption and (c) emission spectra of OXN$2(5 \mu \mathrm{M})$ and chemically synthesized 6-DMMNA $(5 \mu \mathrm{M}$, compound 9) in $\mathrm{pH} 7.0$. The emission spectra were recorded under excitation at the maximum absorption wavelength. 
(a) OXN-1
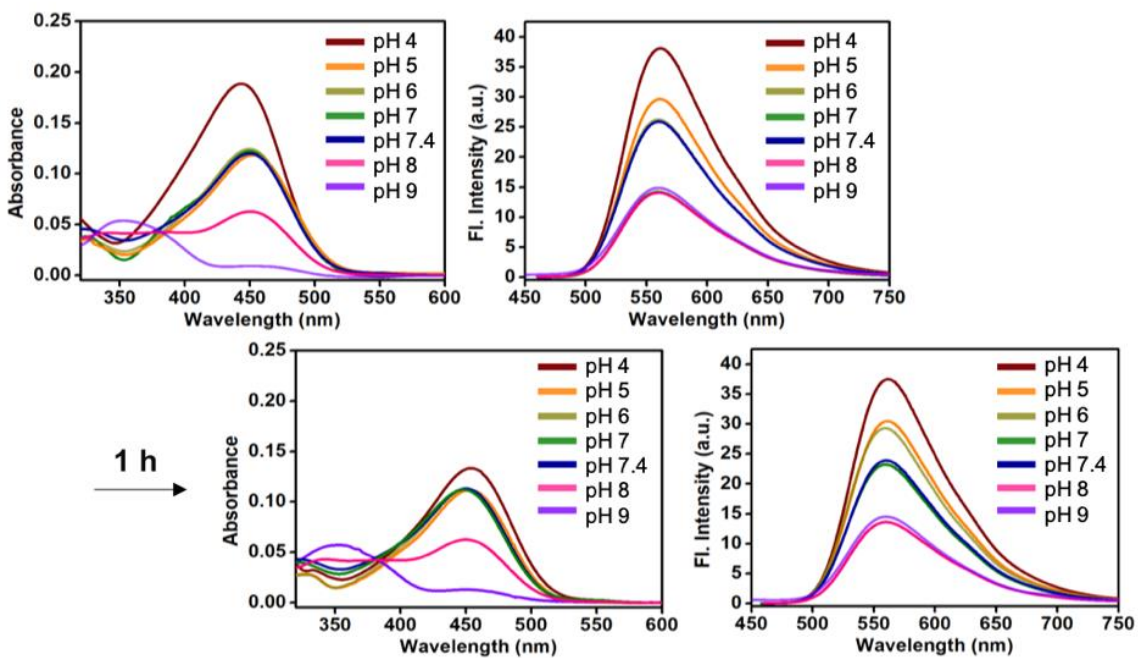

(b) OXN-2
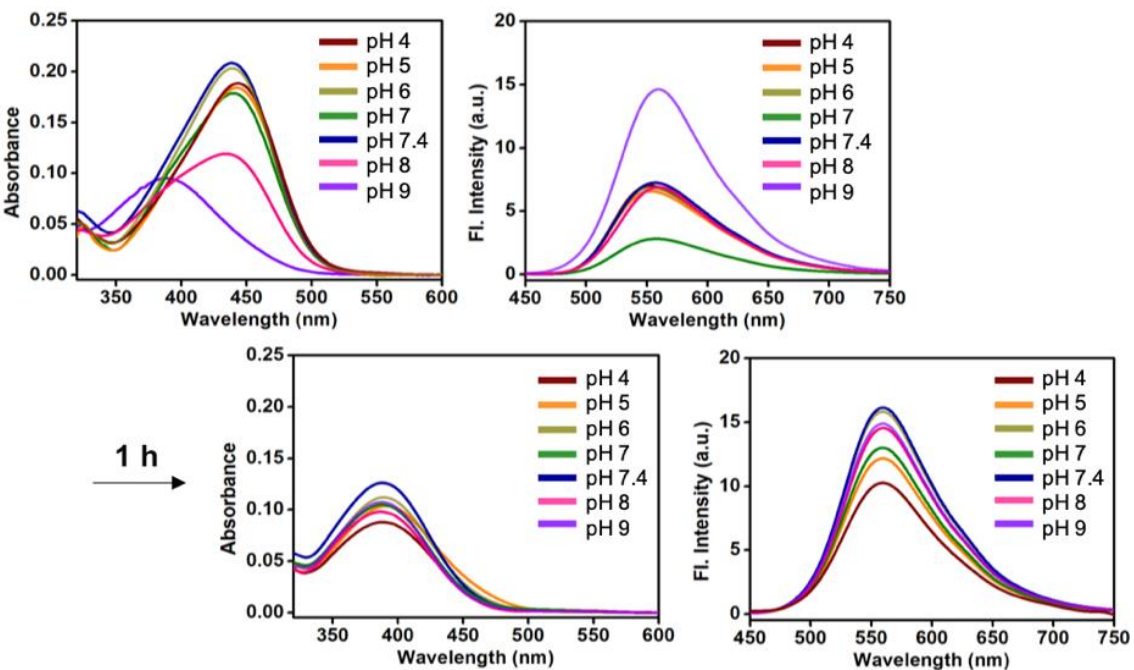

Figure S7. (a) UV/vis absorption and emission spectra of $\mathbf{O X N - 1}$ and (b) $\mathbf{O X N}-\mathbf{2}$ in various pHs (pH 4, 5, 6, 7, 8, 9, 7.4, 8, and 9). (Upper) Before incubation (Bottom) After incubate $1 \mathrm{~h}$ at $25^{\circ} \mathrm{C}$. All the measurements were carried out at $25^{\circ} \mathrm{C}$ for a solution of the $\mathbf{O X N}-1$ and $\mathbf{O X N}-2(5 \mu \mathrm{M})$. The emission spectra were recorded under excitation at the maximum absorption wavelength. 

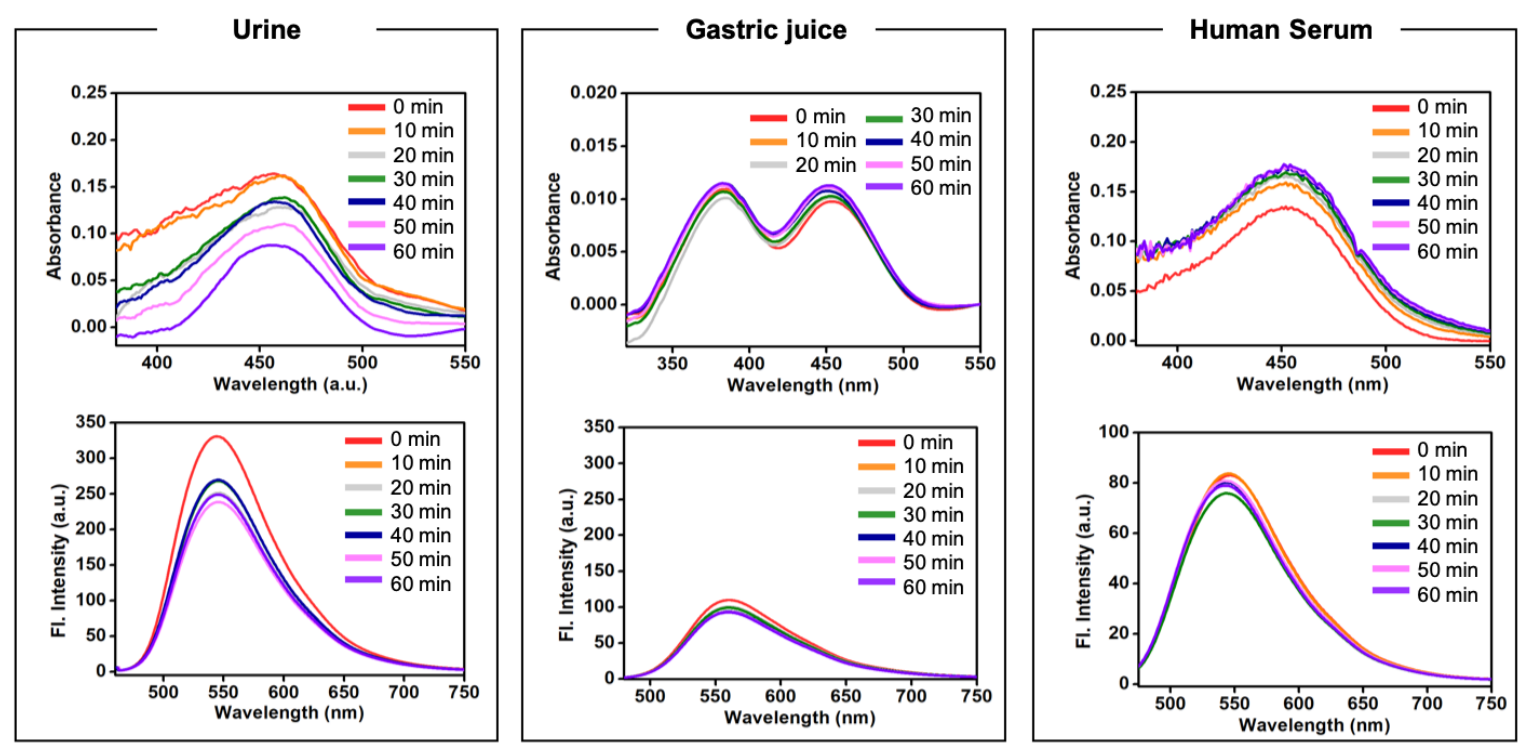

Figure S8. Time-dependent absorption and emission spectra of $\mathbf{O X N - 1}$ with urine (left), gastric juice (middle), and human serum (right). Absorption and emission spectra changes of $\mathbf{O X N - 1}(5 \mu \mathrm{M})$ upon addition of each bio-fluid (left: urine, middle: gastric juice, right: human serum) in $\mathrm{DI}_{2} \mathrm{O}$ at $25{ }^{\circ} \mathrm{C}$. The emission spectra were measured under excitation at $452-455 \mathrm{~nm}$. Each spectrum was recorded at 0-60 min (10 min interval) after mixing. 
(a) OXN-1
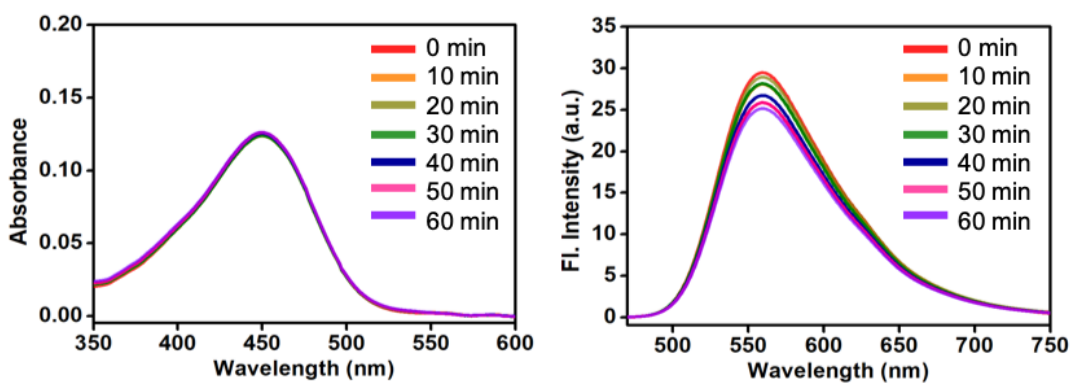

(b) OXN-2
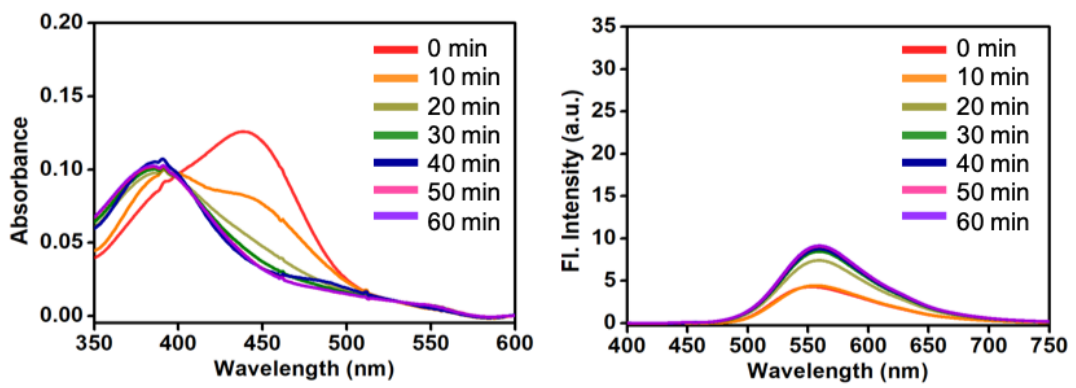

Figure S9. (a) UV/vis absorption and emission spectra of $\mathbf{O X N - 1}$ and (b) $\mathbf{O X N}-2$ at the given time points under continues UV irradiation $(365 \mathrm{~nm}, 6 \mathrm{~W})$. All the measurements were carried out at $25^{\circ} \mathrm{C}$ for a solution of the OXN-1 $(5 \mu \mathrm{M})$ and $\mathbf{O X N}-2(5 \mu \mathrm{M})$ in DI $\mathrm{H}_{2} \mathrm{O}$. The emission spectra were recorded under excitation at the maximum absorption wavelength. 
(a)

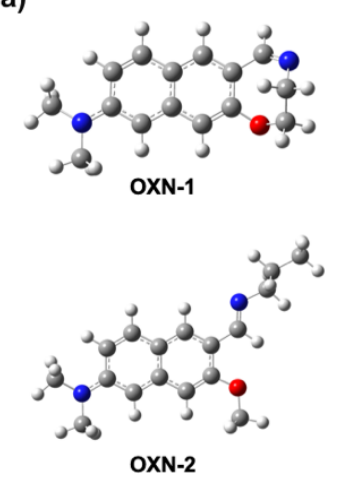

(b)

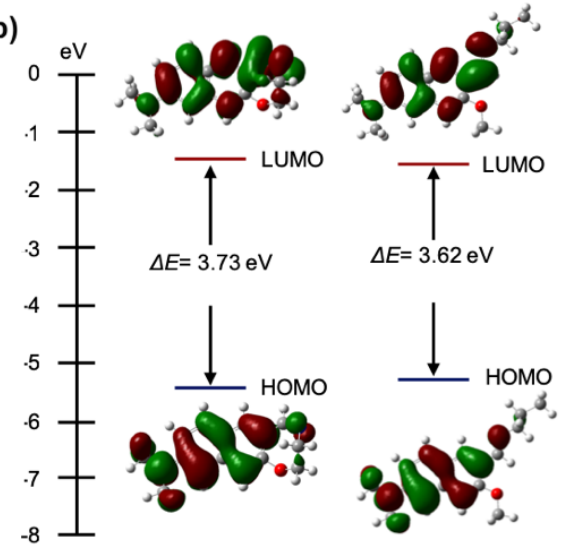

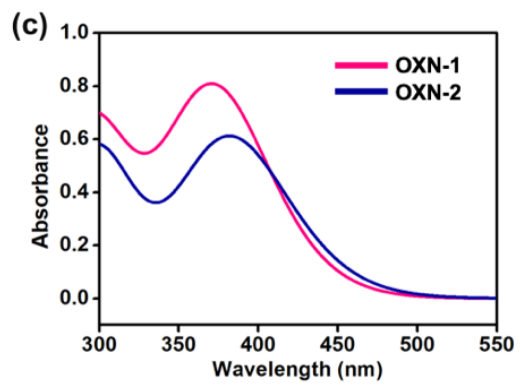

Figure S10. (a) Optimized structures of OXN series calculated using the B3LYP-d3/6-31+G(d,p). (b) The HOMO and LUMO orbitals and their energies for OXN series. (c) Calculated absorption spectra of OXN series. 

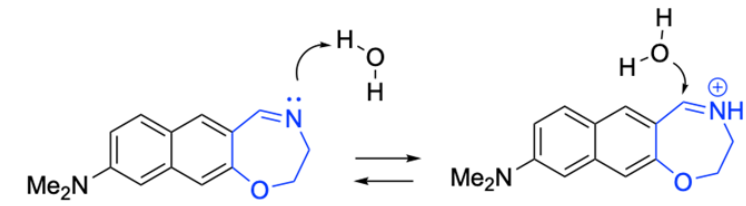

$\longleftrightarrow$
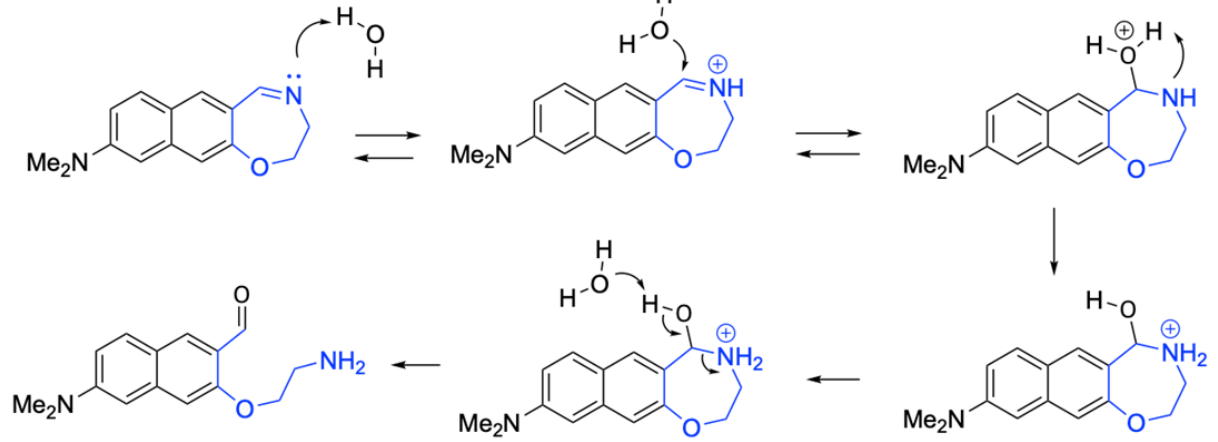

Figure S11. The proposed mechanism of OXN-1 hydrolysis. 

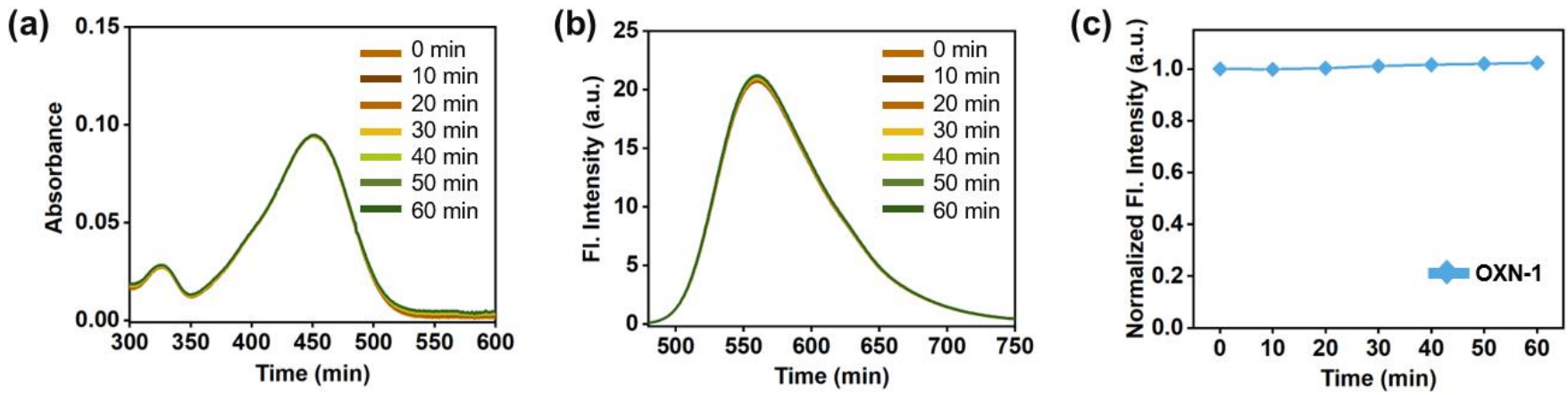

Figure S12. Time-dependent (a) absorption and (b) emission spectra of $\mathbf{O X N - 1}(5 \mu \mathrm{M})$ with glutathione (GSH, $10 \mathrm{mM}$ ) in phosphate-buffered saline (PBS, $\mathrm{pH} 7.4$ ) at $25^{\circ} \mathrm{C}$. The emission spectra were measured under excitation at $450 \mathrm{~nm}$. Each spectrum was recorded at 0-60 min (10 min interval) after mixing. (c) normalized fluorescence intensity plot from panel (b) at maximum emission wavelength. 


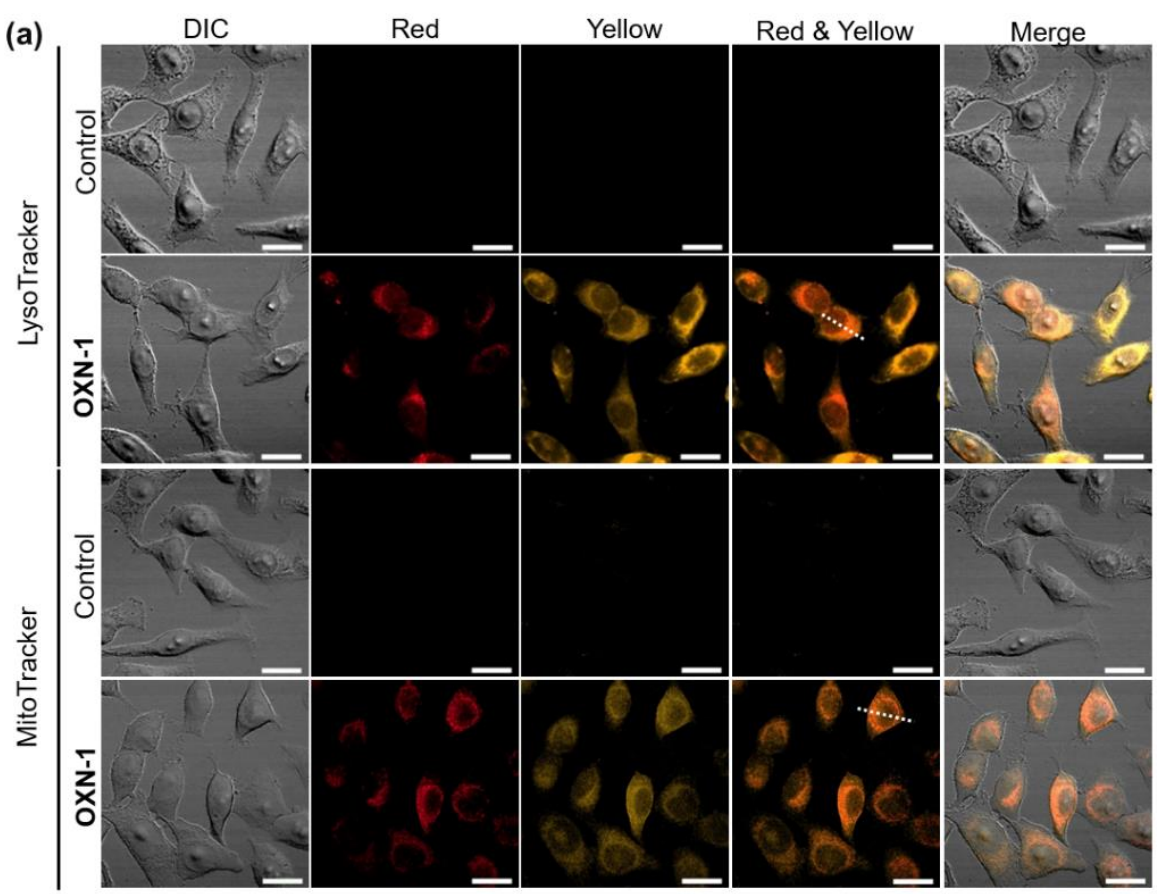

(b)

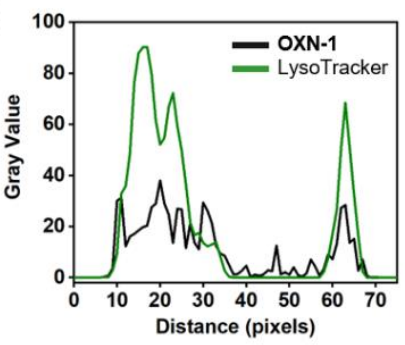

(c)

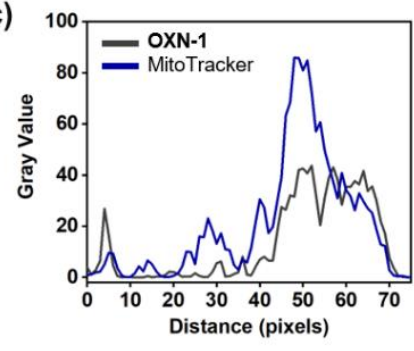

Figure S13. CLSM images of HeLa cells co-labeled with (a) OXN-1 with LysoTracker Deep-red, and OXN1 with MitoTracker Deep-Red for $30 \mathrm{~min}$ at $37{ }^{\circ} \mathrm{C}$. Excitation wavelength: $450 \mathrm{~nm}$ for $\mathbf{O X N}-1,647 \mathrm{~nm}$ for LysoTracker Deep-Red, and $644 \mathrm{~nm}$ for MitoTracker Deep-Red. (b) Fluorescence intensity plot along with the dotted line (white color) in the merged images. The emission was collected in a window of 450-617 nm for yellow-emitting dye (OXN-1), 645-700 nm for red-emitting dye (LysoTracker Deep-Red), and 645-700 $\mathrm{nm}$ for red-emitting dye (MitoTracker Deep-Red). Scale bar is $20 \mu \mathrm{m}$. 


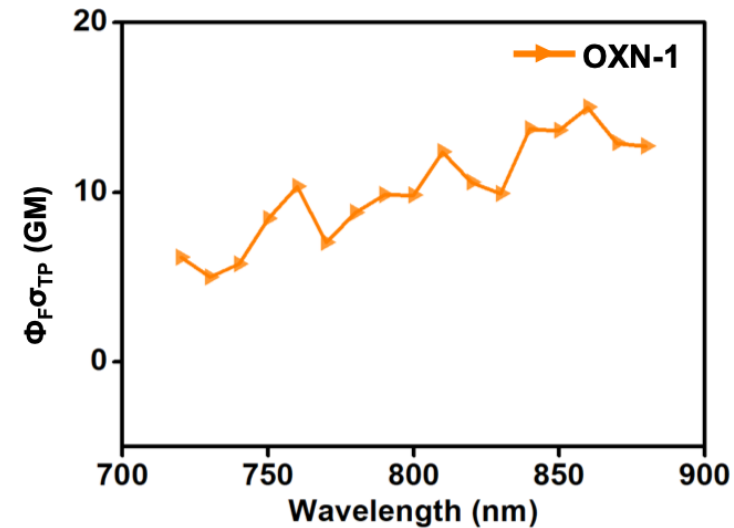

Figure S14. Two-photon action cross-sections (TPACS, GM value) of OXN-1 in DMSO $(10 \mu \mathrm{M})$. 


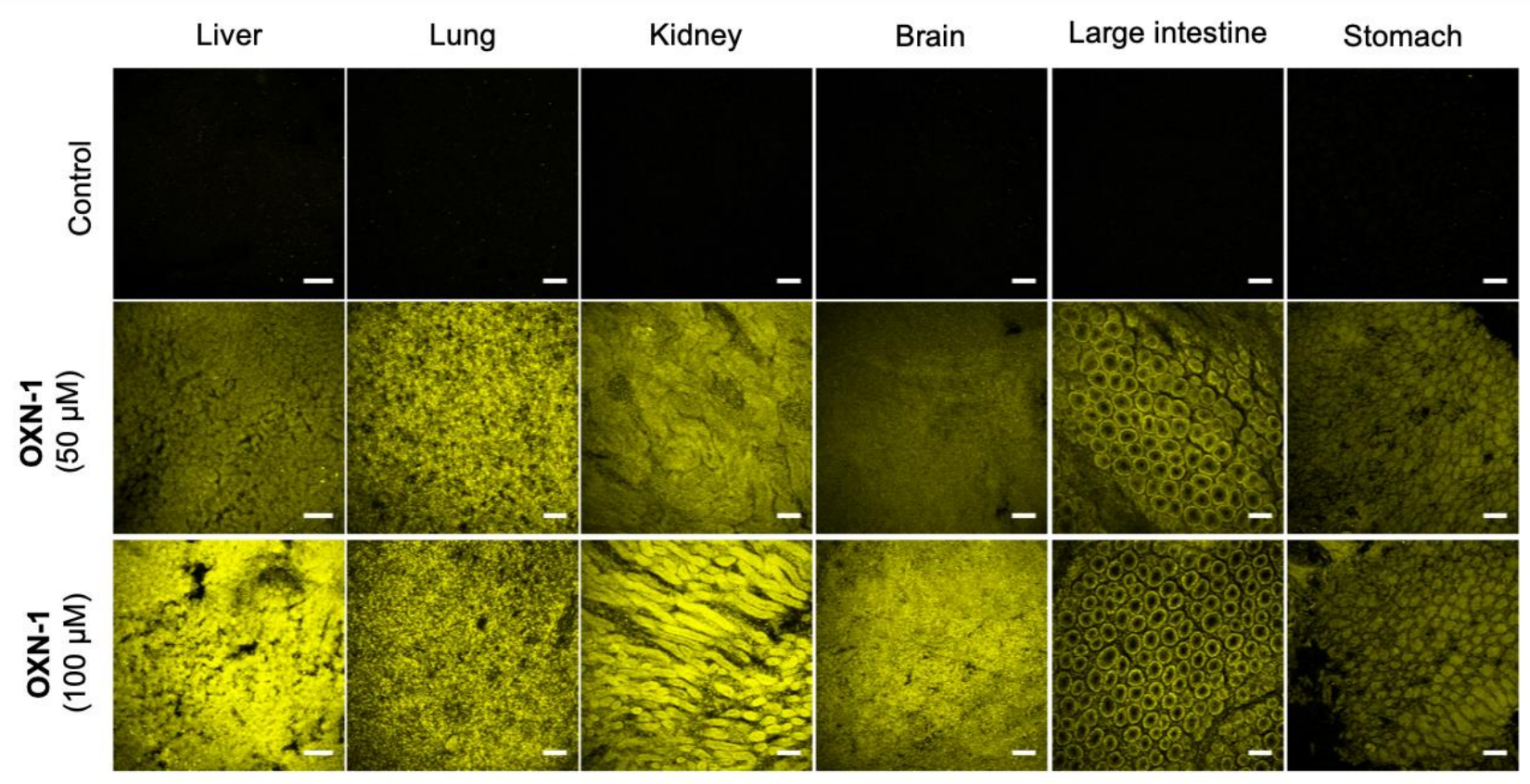

Figure S15. TPM images of different mouse organ tissues, incubated with $\mathbf{O X N}-\mathbf{1}(50 \mu \mathrm{M}, 100 \mu \mathrm{M})$ at a middle depth layer $(\sim 85 \mu \mathrm{m})$ of sectioned tissues for $2 \mathrm{~h}$ at $37{ }^{\circ} \mathrm{C}$. TPM images obtained by collecting the fluorescence from an emission channel of 569-611 nm, under excitation at $543 \mathrm{~nm}$ with laser power of approximately $50 \mathrm{~mW}$ at the focal plane. Scale bar: $100 \mu \mathrm{m}$. 
Liver

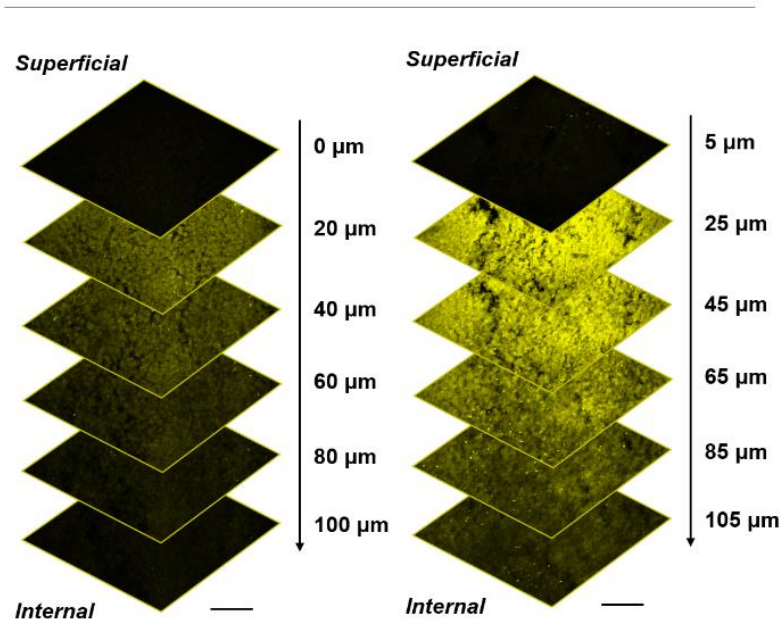

Kidney
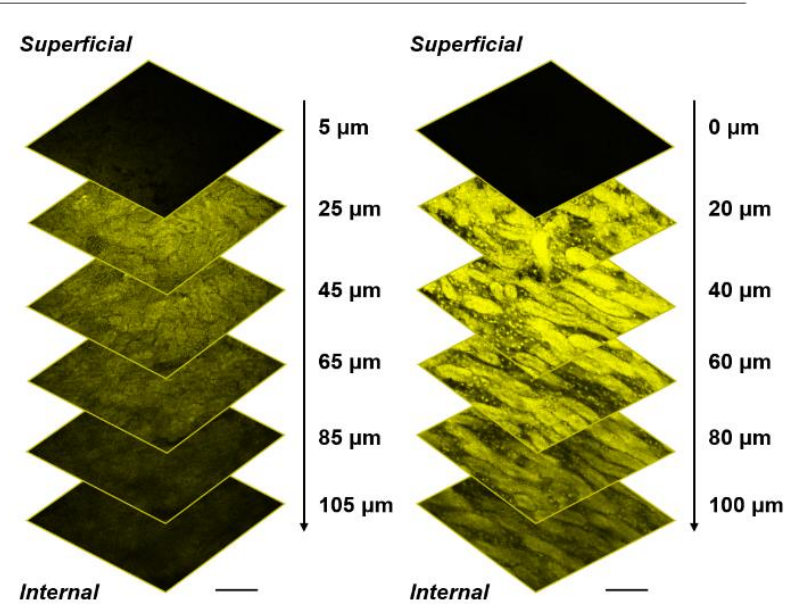

Large intestine
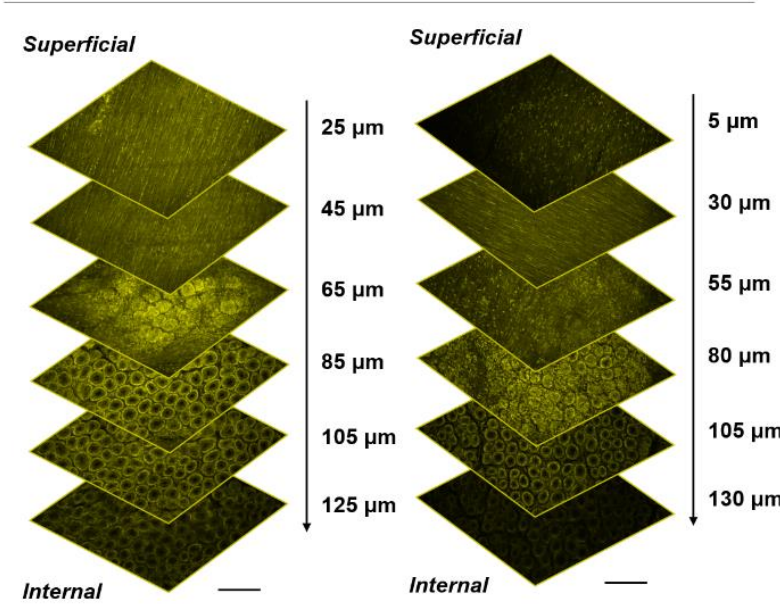
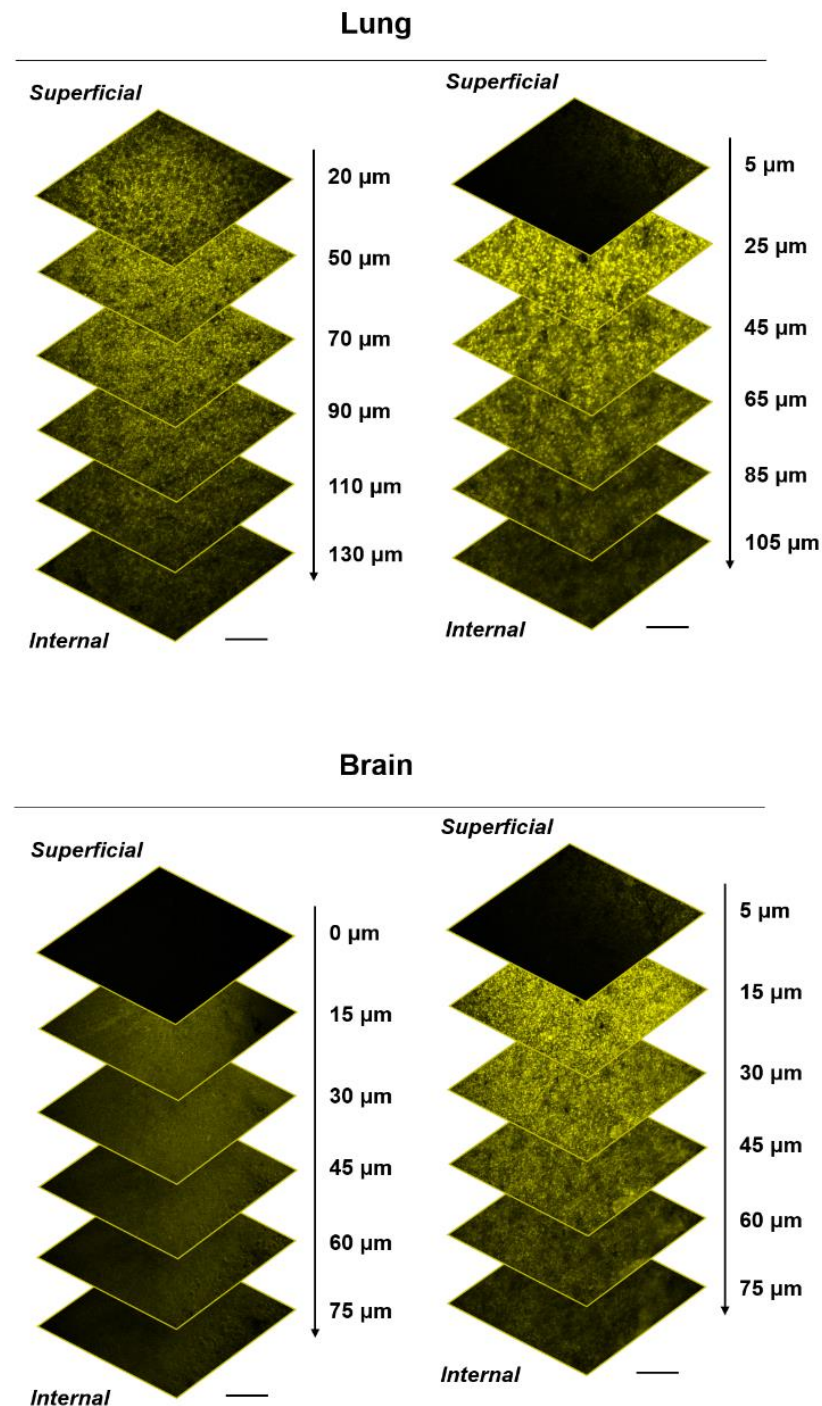

Internal

\section{Stomach}
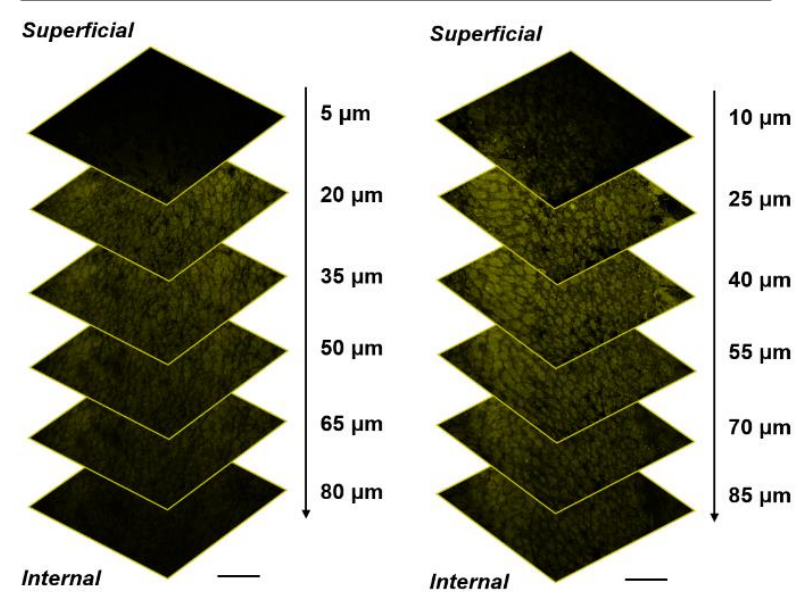

Figure S16. TPM images of mouse organ tissues at the indicated depths incubated with $\mathbf{O X N}-\mathbf{1}(50 \mu \mathrm{m}$ for left, $100 \mu \mathrm{m}$ for right). Scale bar: $200 \mu \mathrm{m}$. 


\section{Supporting Table}

Table S1. Photophysical properties of OXN-1 and OXN-2 in various solvents (ACN: acetonitrile, DCM: dichloromethane, DMSO: dimethyl sulfoxide, EtOAc: ethyl acetate, PhMe: toluene, THF: tetrahydrofuran, iPA: isopropylalcohol; DMF: dimethyl formamide, $\mathrm{DI} \mathrm{H}_{2} \mathrm{O}$ : deionized water). $10 \mu \mathrm{M}$ solutions of compounds in a given solvent were used for all measurements. The fluorescence spectrum was recorded after excitation at the maximum absorption wavelength in a given solvent. The fluorescence quantum yield (QY) of $\mathbf{O X N}-\mathbf{1}$ and $\mathbf{O X N - 2}$ were determined using DPA as a reference dye.

\begin{tabular}{|c|c|c|c|c|c|c|}
\hline Compounds & Solvents & $\lambda_{\text {abs }}(\mathrm{nm})$ & $\varepsilon\left(\mathrm{L} \mathrm{mol}^{-1} \mathrm{~cm}^{-1}\right)$ & $\lambda_{\mathrm{fl}}(\mathrm{nm})$ & Stokes shift & QY \\
\hline \multirow{9}{*}{ OXN-1 } & $\mathrm{ACN}$ & 456 & 6,455 & 562 & 106 & \\
\hline & DCM & 450 & 6,682 & 532 & 83 & \\
\hline & DMSO & 359 & 5,168 & 447 & 88 & 0.70 \\
\hline & EtOAc & 354 & 5,497 & 426 & 72 & \\
\hline & $\mathrm{PhMe}$ & 355 & 5,657 & 415 & 60 & \\
\hline & THF & 353 & 4,646 & 425 & 72 & \\
\hline & iPA & 362 & 7,039 & 447 & 85 & \\
\hline & DMF & 362 & 6,364 & 442 & 80 & \\
\hline & $\mathrm{DI} \mathrm{H}_{2} \mathrm{O}$ & 451 & 9,337 & 559 & 108 & \\
\hline \multirow{9}{*}{ OXN-2 } & $\mathrm{ACN}$ & 369 & 5,955 & 448 & 79 & \\
\hline & $\mathrm{DCM}$ & 368 & 7,156 & 434 & 66 & \\
\hline & DMSO & 376 & 7,622 & 456 & 80 & 0.61 \\
\hline & EtOAc & 369 & 6,835 & 441 & 72 & \\
\hline & $\mathrm{PhMe}$ & 369 & 7,758 & 418 & 49 & \\
\hline & THF & 369 & 7,530 & 429 & 60 & \\
\hline & iPA & 450 & 11,989 & 547 & 97 & \\
\hline & $\mathrm{DMF}$ & 374 & 7,374 & 449 & 75 & \\
\hline & DI $\mathrm{H}_{2} \mathrm{O}$ & 438 & 10,779 & 556 & 118 & \\
\hline
\end{tabular}

Table S2. The HOMO and LUMO energies, their gap $\left(E_{\mathrm{g}}\right)$, and absorption maximum $\left(\lambda_{\max }\right)$ of $\mathbf{O X N} \mathbf{- 1}$ and OXN-2 calculated by the DFT methods.

\begin{tabular}{|c|c|c|c|c|}
\hline & $E_{\text {номо }}(\mathrm{eV})$ & $E_{\text {LUмо }}(\mathrm{eV})$ & $E_{\mathrm{g}}(\mathrm{eV})$ & $\lambda_{\max }(\mathrm{nm})^{\mathrm{a}}$ \\
\hline OXN-1 & -5.38 & -1.65 & 3.73 & 373.3 \\
\hline OXN-2 & -5.30 & -1.68 & 3.62 & 383.5 \\
\hline
\end{tabular}

${ }^{a} \lambda_{\max }$ is obtained by using TD-DFT method. 
${ }^{1} \mathrm{H}$ and ${ }^{13} \mathrm{C}$ NMR Spectra for the Synthesized Compounds

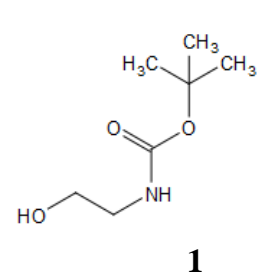

î.
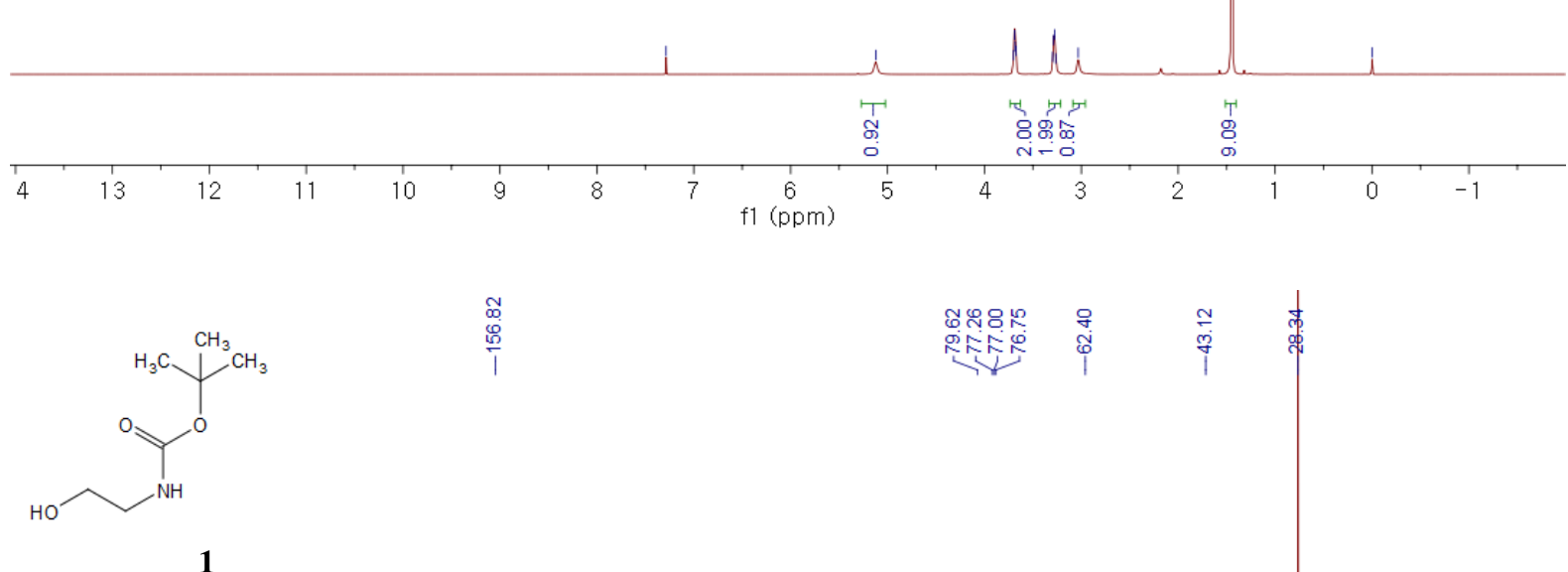

$\underset{\substack{0 \\ 0}}{\substack{\Gamma \\ \hdashline}}$

繁先

1

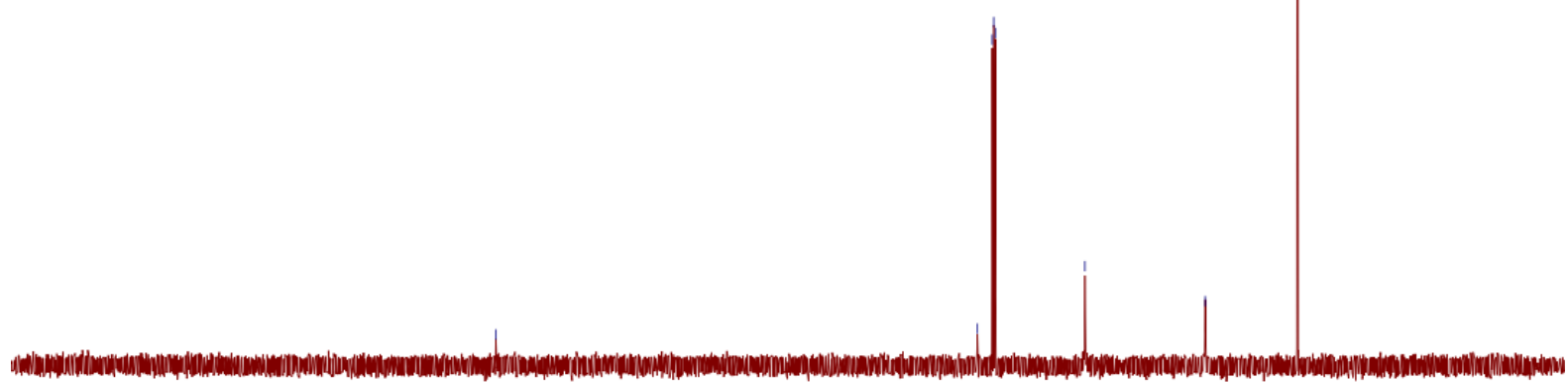

$\begin{array}{lllllllllllllllllllllllllll}230 & 220 & 210 & 200 & 190 & 180 & 170 & 160 & 150 & 140 & 130 & 120 & 110 & 100 & 90 & 80 & 70 & 60 & 50 & 40 & 30 & 20 & 10 & 0 & -10\end{array}$ 


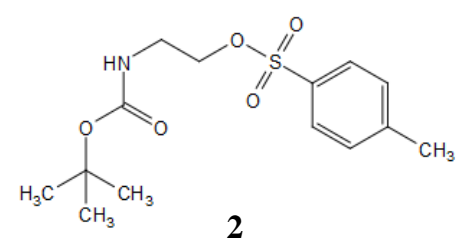

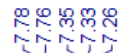

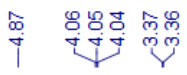

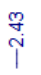

$\stackrel{8}{i}$
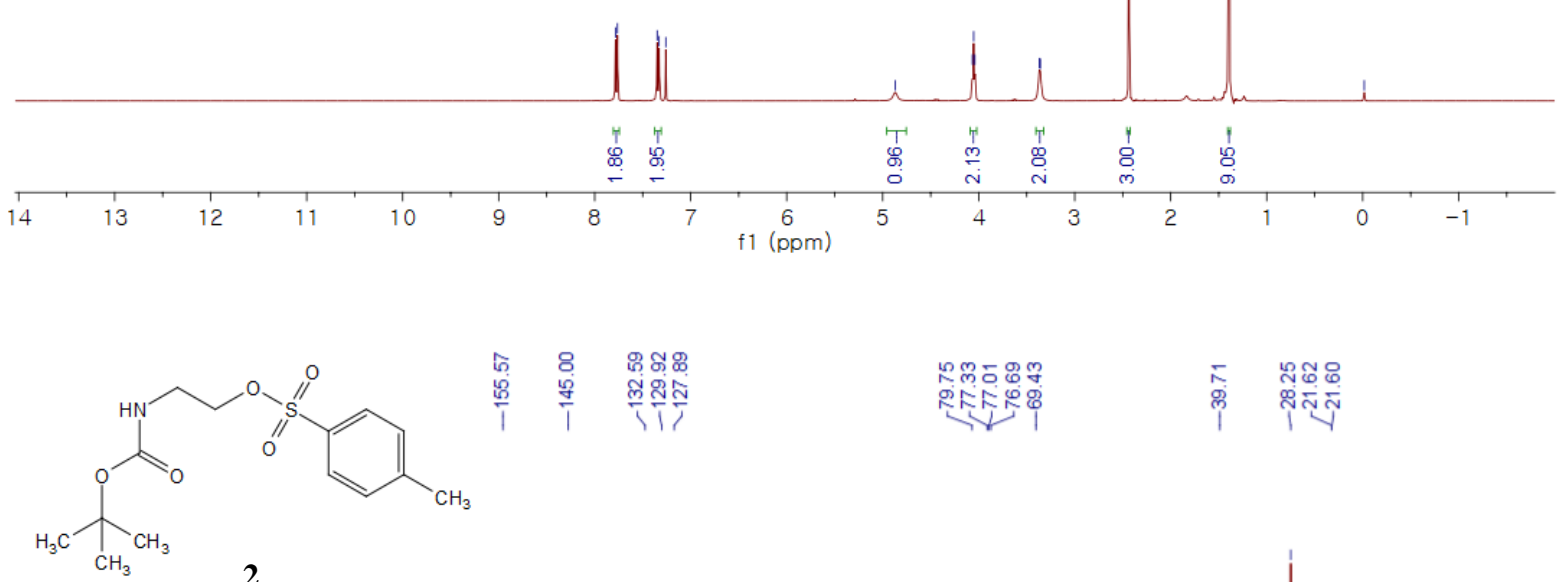

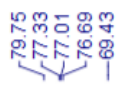
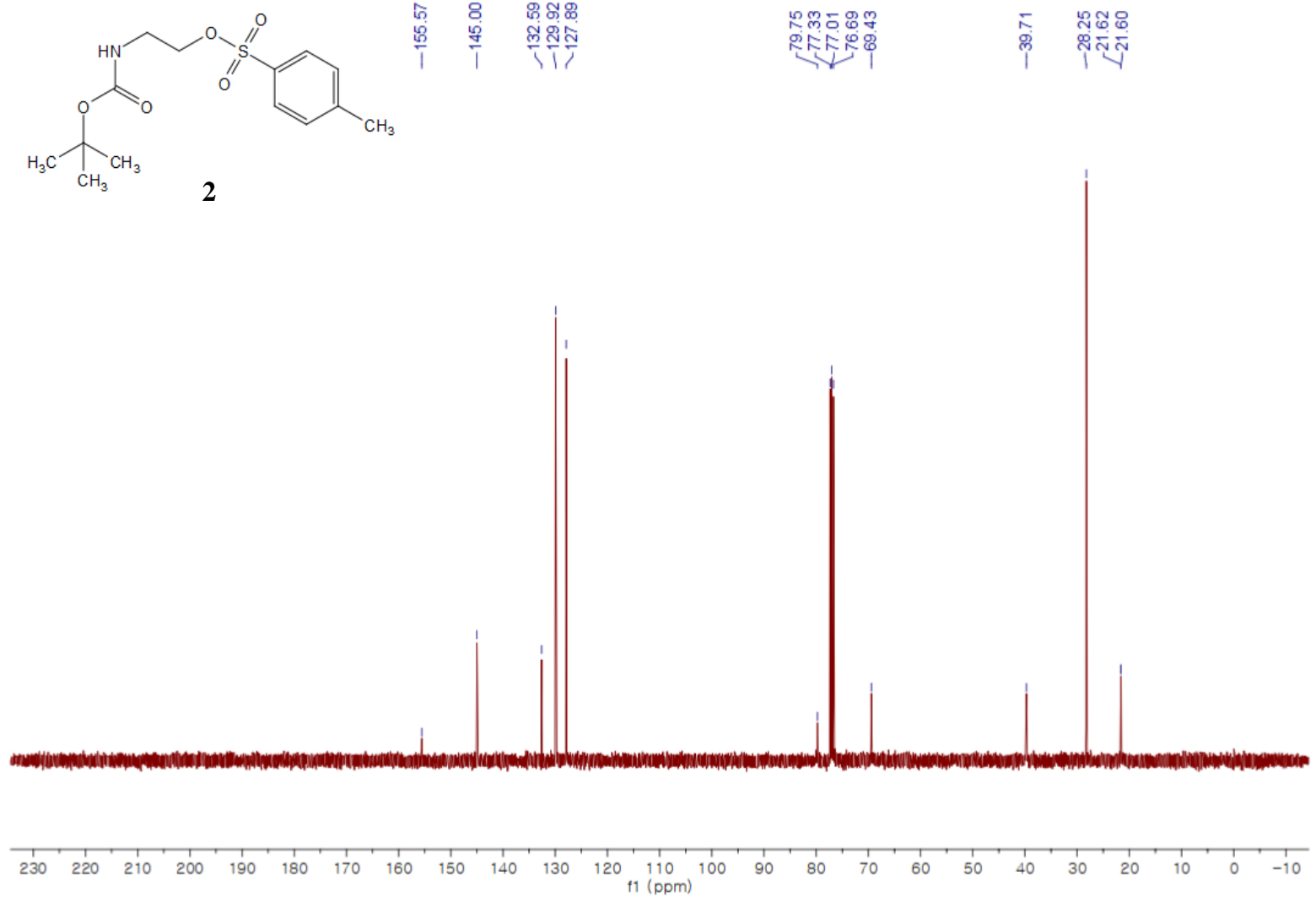

S26 

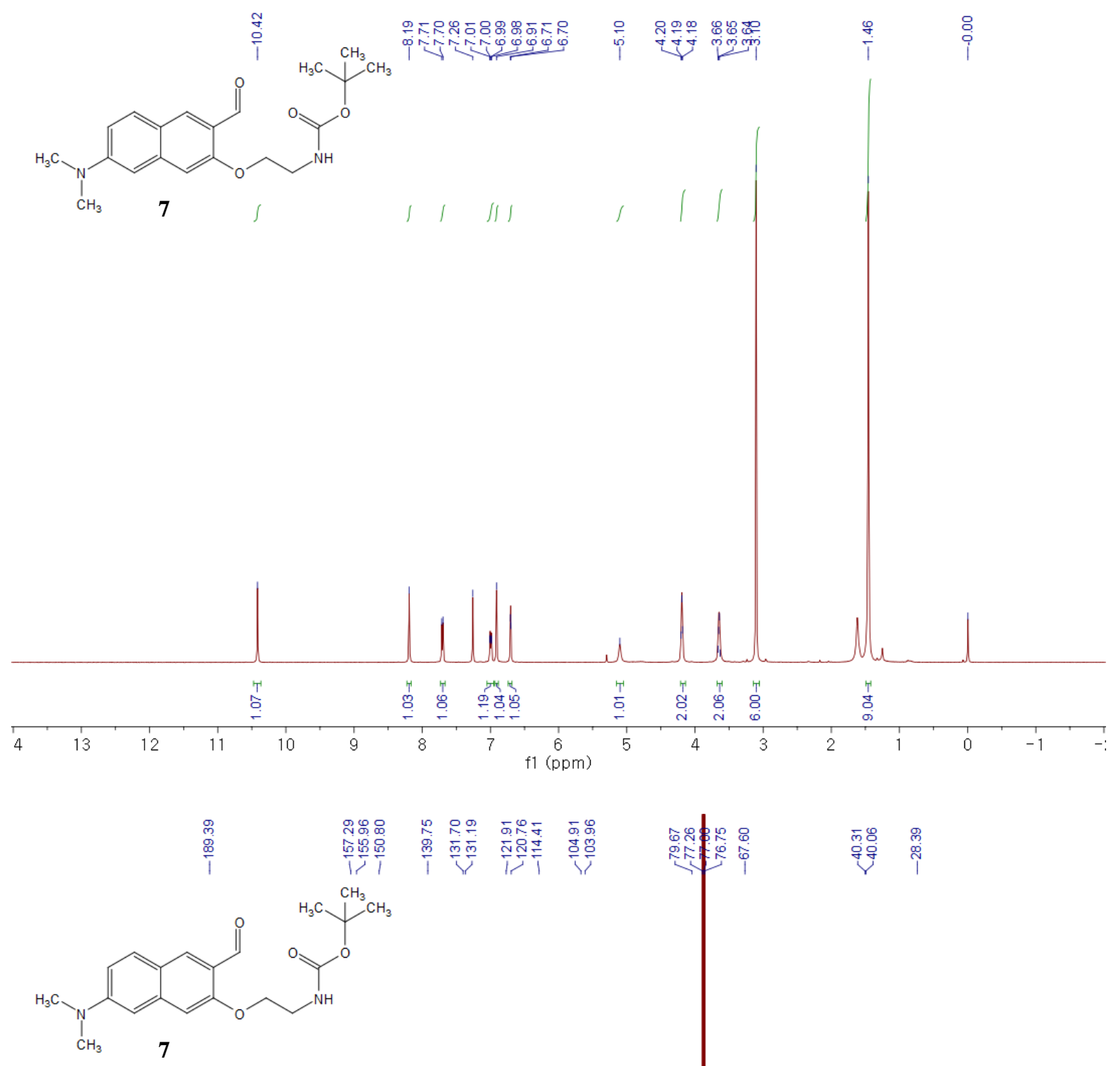

ํํㅁ

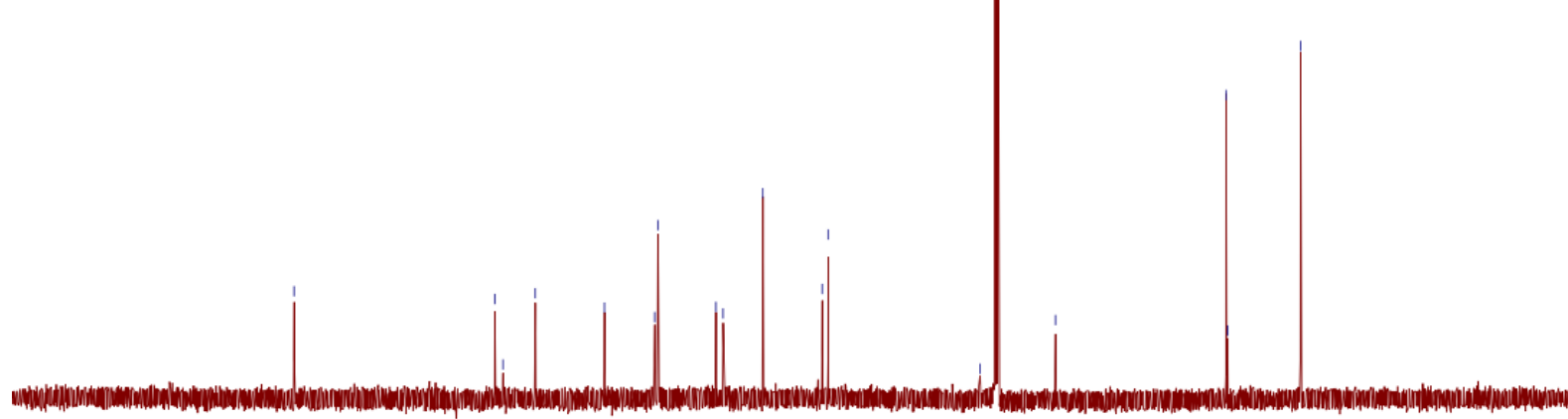

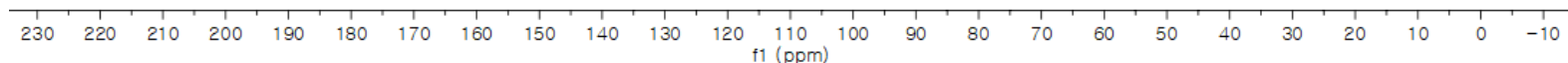



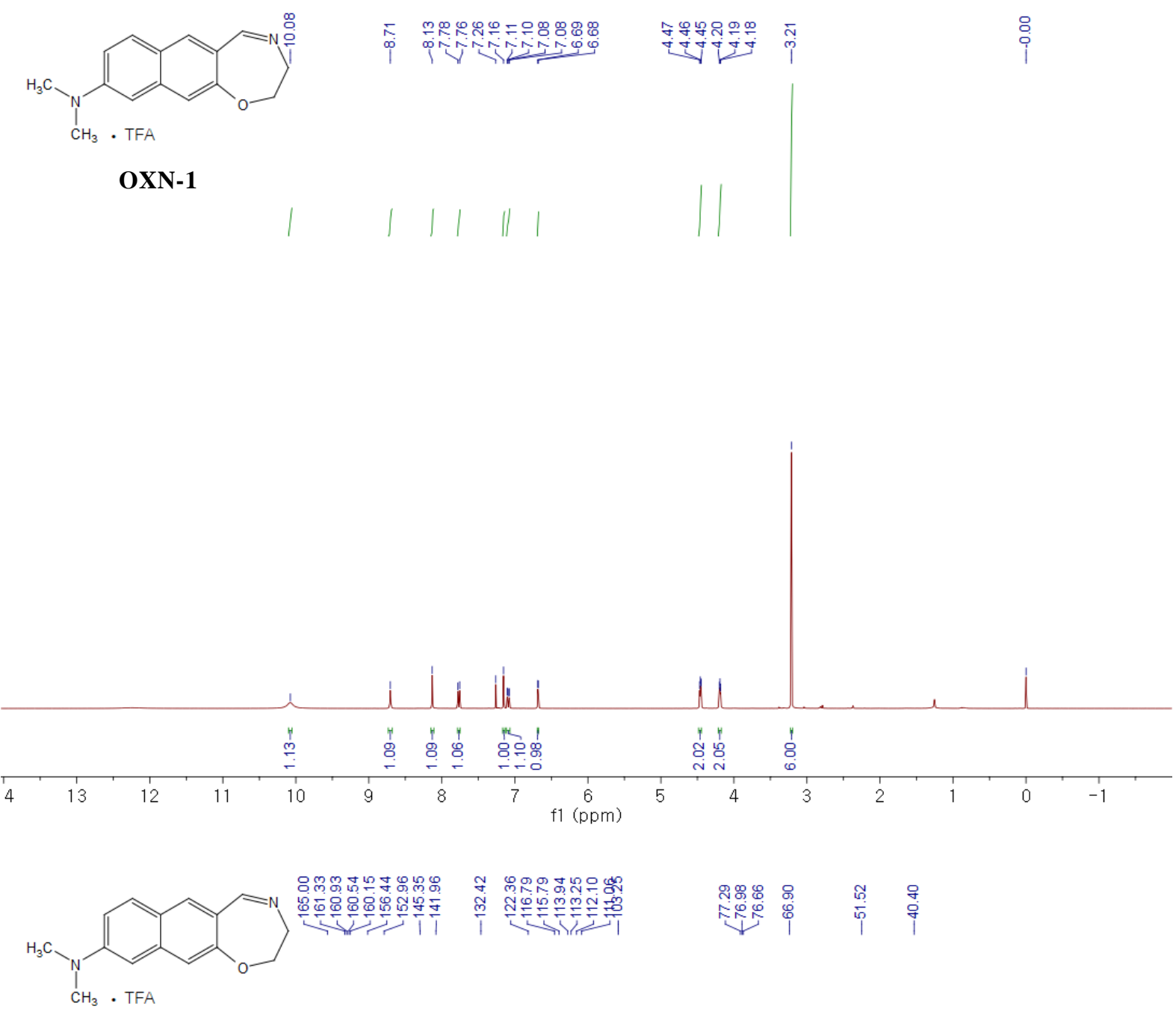

OXN-1

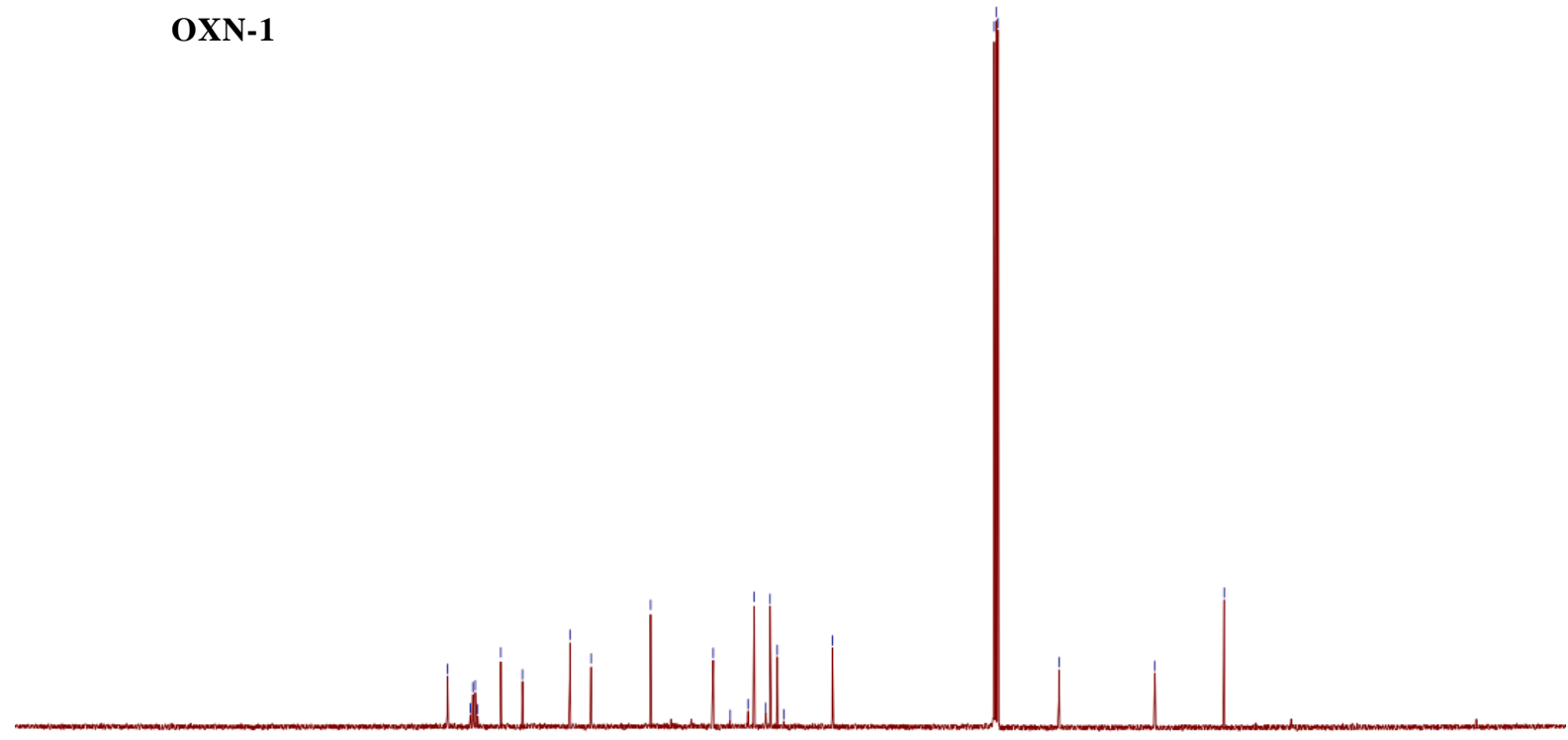

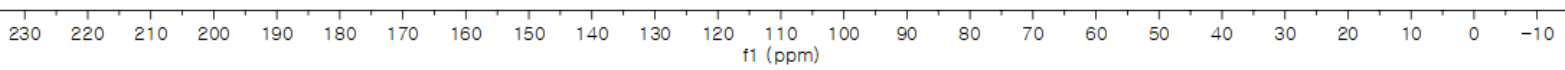



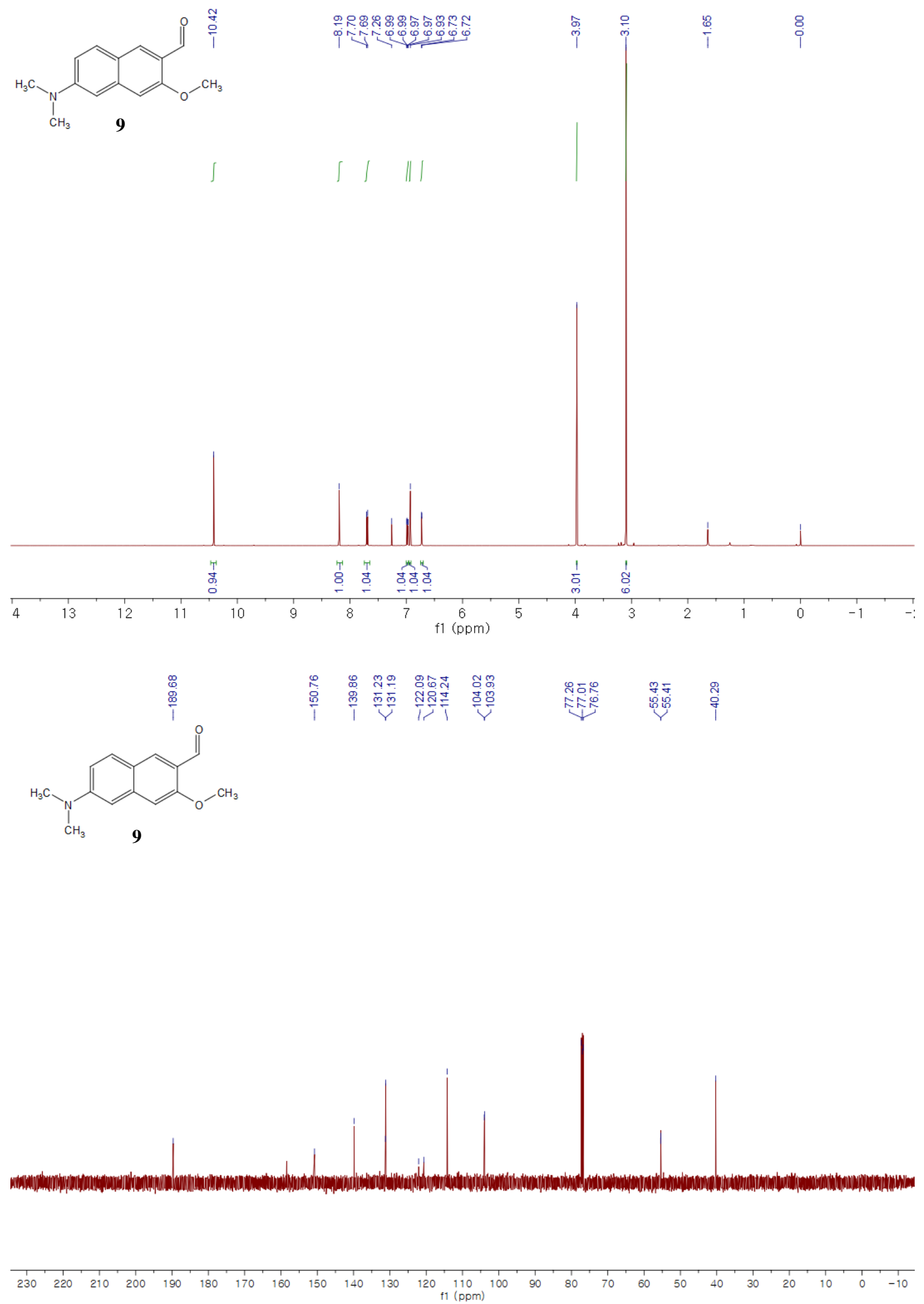

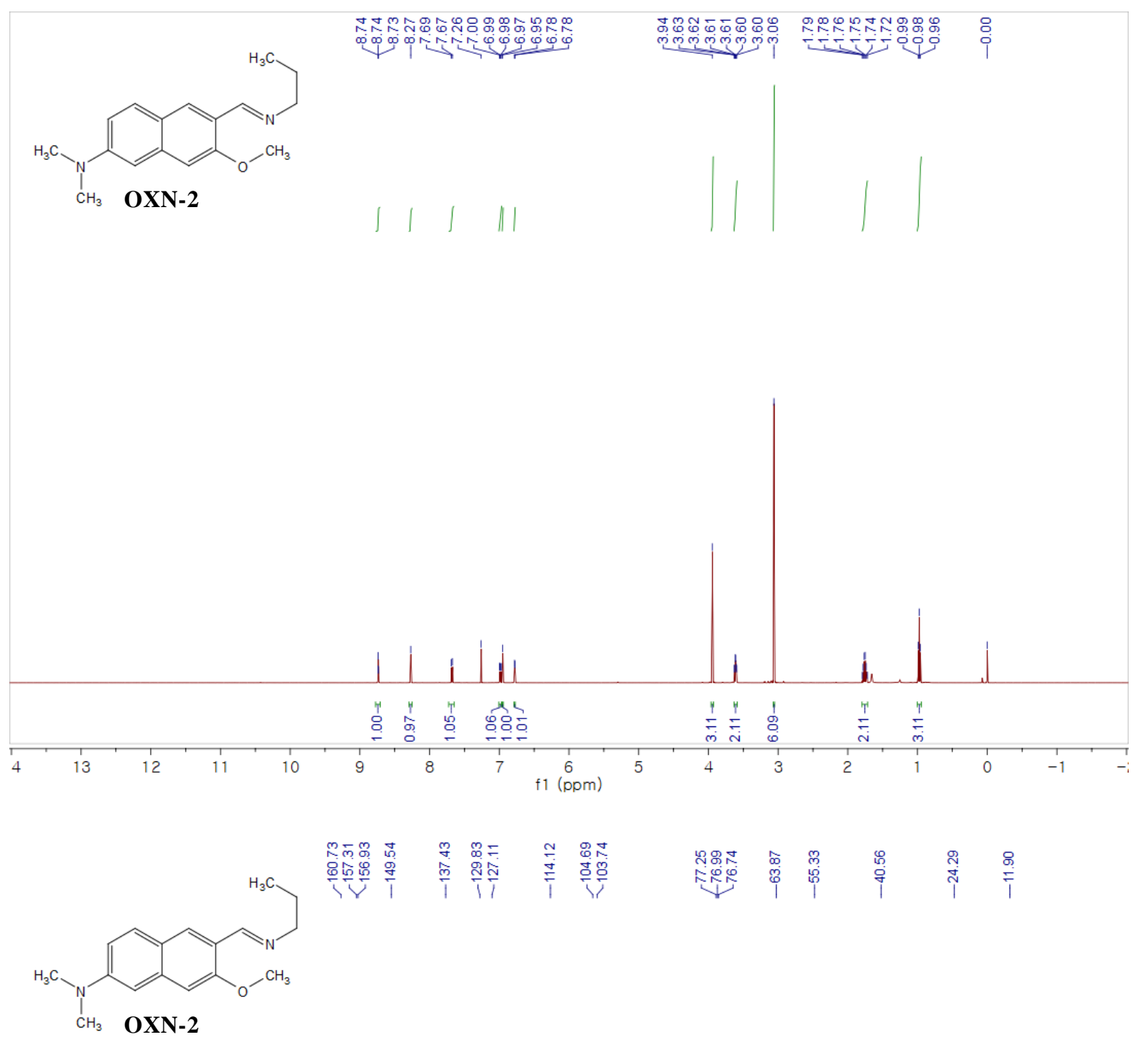

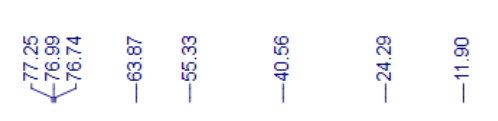

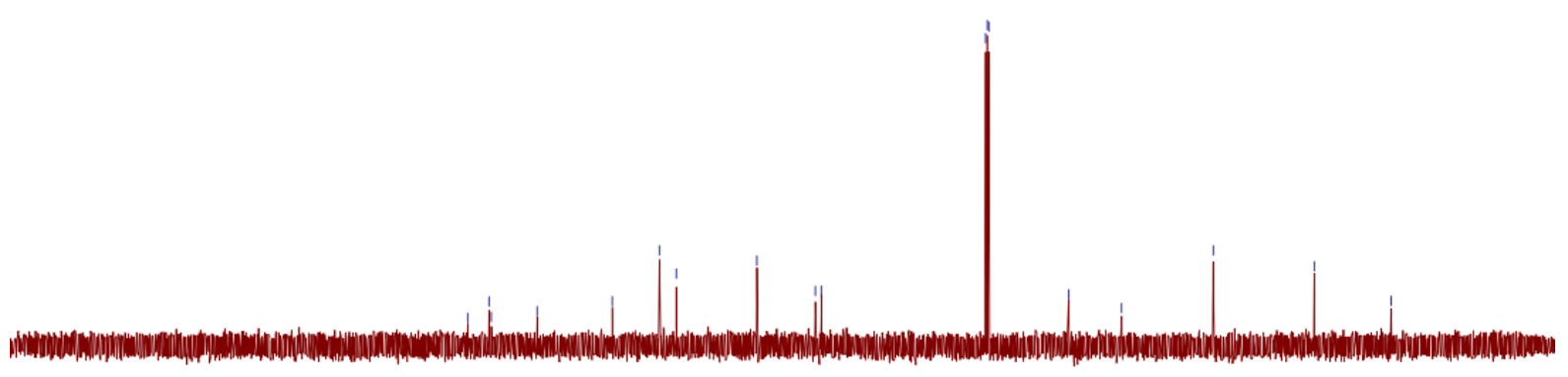

\begin{tabular}{lllllllllllllllllllllllllllll}
\hline & 10 & 220 & 210 & 200 & 190 & 180 & 170 & 160 & 150 & 140 & 130 & 120 & 110 & 100 & 90 & 80 & 70 & 60 & 50 & 40 & 30 & 20 & 10 & 0 & -10
\end{tabular}

S30 


\section{References and Notes}

[1] Kim, I., et al., Synthesis of $\pi$-extended coumarins and evaluation of their precursors as reactive fluorescent probes for mercury ions, Asian J. Org. Chem., 2012, 1, 60-64.

[2] Frisch, M. J., et al., Gaussian 09, Rev. E. 01, Gaussian, Inc., Wallingford, CT, 2013 